IZA DP No. 6698

Joint Leisure Before and After Retirement:

A Double Regression Discontinuity Approach

Elena Stancanelli

Arthur Van Soest

June 2012 


\title{
Joint Leisure Before and After Retirement: A Double Regression Discontinuity Approach
}

\author{
Elena Stancanelli \\ CNRS, Sorbonne Economic Research Center, \\ IZA and OFCE, Sciences-Po \\ Arthur Van Soest \\ Netspar, Tilburg University, \\ RAND and IZA
}

\section{Discussion Paper No. 6698 \\ June 2012}

IZA

P.O. Box 7240

53072 Bonn

Germany

Phone: +49-228-3894-0

Fax: +49-228-3894-180

E-mail: iza@iza.org

Any opinions expressed here are those of the author(s) and not those of IZA. Research published in this series may include views on policy, but the institute itself takes no institutional policy positions.

The Institute for the Study of Labor (IZA) in Bonn is a local and virtual international research center and a place of communication between science, politics and business. IZA is an independent nonprofit organization supported by Deutsche Post Foundation. The center is associated with the University of Bonn and offers a stimulating research environment through its international network, workshops and conferences, data service, project support, research visits and doctoral program. IZA engages in (i) original and internationally competitive research in all fields of labor economics, (ii) development of policy concepts, and (iii) dissemination of research results and concepts to the interested public.

IZA Discussion Papers often represent preliminary work and are circulated to encourage discussion. Citation of such a paper should account for its provisional character. A revised version may be available directly from the author. 


\section{ABSTRACT}

\section{Joint Leisure Before and After Retirement: A Double Regression Discontinuity Approach ${ }^{*}$}

In the scant literature on partners' joint retirement decisions one of the explanations for joint retirement is externalities in leisure. In this study, we investigate how retirement affects the hours of leisure together of individuals in a couple. Exploiting the law on retirement age in France, we use a regression discontinuity approach to identify the causal effect of retirement on hours of leisure separate and together of individuals in a couple. We find that the retirement probability increases significantly at age 60 for both partners, supporting our identification strategy. We conclude that retirement of the husband significantly increases own hours of leisure of the husband but it does not increase joint leisure hours of the couple. Retirement of the wife increases joint leisure. This asymmetry in responses is well in line with recent literature on joint retirement and suggests that leisure complementarities may not be the main engine of joint retirement.

JEL Classification: $\quad$ D13, J22, J14, C1

Keywords: leisure, ageing, retirement, regression discontinuity

Corresponding author:

Elena Stancanelli

CNRS - Centre national de la recherche scientifique

3 , rue Michel-Ange

75794 Paris cedex 16

France

E-mail: elenastancanelli@free.fr

\footnotetext{
* Earlier versions of this paper were presented at the Society of Labor Economists Chicago in May 2012, and at a workshop on the Economics of Gender, Nice, June 2012. We thank all participants for comments. All errors are ours.
} 


\section{Introduction}

In the scant literature on partners' joint retirement decisions one of the explanations for joint retirement is externalities in leisure, but these studies did not consider data on the extent to which partners spend their leisure time together. Here we study the causal effect of retirement on leisure hours of partners, using data that allow us to distinguish joint leisure hours from separate leisure hours of each partner.

Because individuals with stronger preferences for leisure may tend to retire earlier, we allow the retirement status of both partners to be endogenous in the equations for joint and separate leisure of partners. Our identification strategy exploits the law that in France, age 60 is the earliest age at which a retirement pension can be drawn. This makes each partner's probability to be in retirement a discontinuous function of their age, with a substantial positive jump at age 60 . We therefore can use a (double) regression discontinuity approach to identify the effect of own and partner's retirement on leisure hours.

There are several studies on retirement decisions of couples, starting from Michael Hurd (1990). Externalities in leisure are often given as an explanation for the fact that both partners tend to retire at about the same time ("joint retirement"). A major contribution in this area is the structural dynamic model of retirement of couples developed by Alan Gustman and Thomas Steinmeier (2000), who argued that preferences for joint leisure are an important driver of joint retirement choices (see also Casanova, 2010). On the other hand, Gustman and Steinmeier (2009) extend this model to incorporate partial retirement strategies, and argue that in some cases individuals in a couple may decide to retire only if their partner does not retire. They find that in the US, the increased labour force participation of women has actually contributed to lower husbands' hours of market work.

This suggests that joint leisure is not the only relevant story here, and studying whether retirement actually induces changes in the hours of leisure individuals in a couple spend together seems worthwhile to directly address the relevance of the externalities in leisure argument for joint retirement.

Stancanelli and Van Soest (2012) apply a regression discontinuity approach to investigate the causal effect of retirement on hours spent on home production. They find asymmetric responses of housework to partners' retirement: housework of the male partner increases 
dramatically upon retirement, but less so when the wife also retires, while her housework is not much affected by his retirement. They did not consider data on hours of leisure or on how much leisure the two partners spend together.

Studies on actual leisure hours of individuals in a couple are rare and they have not investigated joint leisure in conjunction with retirement, to the best of our knowledge. They have focused on dual-earner households. Hamermesh (2002), using American data for the seventies, concluded that partners adapt their work schedules to be able to enjoy leisure synchronously. Hallberg (2003), matching singles to individuals in couple, and using Swedish data, investigated the effect of working hours schedules on the fact that partners were found to consume leisure at the same time of the day, trying to disentangle what happened to be "synchronous" leisure, from leisure time that partners really 'chose' to spend 'together'. He found that "actively" chosen joint leisure was only a small proportion of synchronized leisure.

Here we model the effect of retirement of both partners on their leisure hours endogenizing retirement of both partners. Our measure of leisure includes about 45 activities ranging from watching television to eating out, doing computer games, reading, going to the movie, visiting friends or relatives, socializing, doing sports, or going for a walk: activities that individuals in a couple would presumably enjoy to do together (see, for example, Aguiar and Hurst (2006), or John Robinson and Geoffrey Godbey, 1997, for excellent reports on leisure issues)..

We use data drawn from a survey for France that collects detailed diary information on the activities carried out by individuals over a full day, the same day for both individuals in a couple. Furthermore, the survey also provides information on timing of the activities, "with whom' and "where" each activity was carried out. We experiment with four different definitions of leisure together of partners, to test for the robustness of our results. Accordingly, we find that in our sample of couples aged 50 to 70 , on a typical day the husband enjoys on average five hours of separate leisure activities and the wife a little less than four hours; while over two hours and a half are spent on average on leisure activities done together, using the narrowest definition. For the broadest definition, on a typical day, the husband spends on average less than four hours of leisure on his own and the wife two hours and a half; while joint leisure averages almost four hours.

Our results indicate that the retirement probability increases significantly for individuals in a couple aged 60 and above, which supports our identification strategy. We also conclude that 
retirement of the husband significantly raises his separate leisure hours but does not have a positive effect on joint leisure hours. Retirement of the wife increases the couple's joint leisure. If retirement is treated as exogenous to the choice of hours of leisure, then either partner retirement is found to increase joint leisure hours.

The structure of this paper is as follows. The next section presents the econometric approach; Section 3 provides details of the data and the sample selection. The exploratory analysis and the results of the estimations are presented in Sections 4 and 5. Section 6 concludes.

\section{A regression discontinuity approach}

To identify the causal effect of retirement on the hours of leisure, we exploit the legislation on early retirement in France, which sets 60 as the earlier retirement age for most workers. This creates a discontinuity in the probability of retirement as a function of age that enables us to apply a regression discontinuity framework. Excellent literature reviews of regression discontinuity methods are provided by, for example, David Lee and Thomas Lemieux, 2010; Wilbert van der Klaauw, 2008; and Guido Imbens and Thomas Lemieux, 2007. A recent application of regression discontinuity to the retirement decision of the head of the household is given in Battistin et al. (2009). Stancanelli and Van Soest (2012) apply a similar regression discontinuity approach to the retirement decision of both partners, focusing, however, on the hours of home production.

Identification of the retirement effect is achieved thanks to the sudden and large increase in the treatment participation at the point of discontinuity (age 60) in the assignment variable (age). Since individuals cannot manipulate their age, this seems a valid assumption in our context. In our design, the probability of retirement is a function of age (and education dummies) and this function is discontinuous at age sixty. In our data, year and month of birth were collected, and also we know the day everyone was interviewed, thus, we assume that age is measured continuously. Furthermore, respondents were asked about their main occupation on the day of the interview and we use answers to this question to define retirement status.

However, we need to account for the fact that some people may retire earlier that sixty -due to special early retirement schemes or specific employment sector rules - and others later. In particular, the pension benefits payable reach a maximum when individuals have cumulated a 
given contribution record (37.5 years of contributions in the private sector, at the time of the survey). ${ }^{1}$ Therefore, individuals that have full pension rights at the early retirement age have no incentive to retire later. On the contrary, those with lesser pension benefit entitlement have a disincentive to retire earlier. Notice, however, that in France unemployment, maternity and sick leave periods all count towards the pension contribution period, so that interrupted labour market experience will not automatically translate into longer work life. Besides, accumulated contribution years are likely to be endogenous to our model as individuals with stronger preferences for leisure might well have had more career breaks and thus fewer contributions years.

It follows that we have a "fuzzy" regression discontinuity design, with a jump in the probability of retirement at age 60 that is greater than zero but less than one. If we would not control for partner's retirement, this would lead to two stage least square regressions of leisure time, instrumenting retirement with an indicator for being age 60 or above (and interactions of such an indicator with (left and right) age polynomials). This is the approach followed, for example, by David Card, Carlos Dobkin and Nicole Maestas (2004 and 2009) who studied the effect of individual health insurance coverage and health related outcomes, exploiting that in the US everyone is eligible to Medicare upon reaching age 65. We use the discontinuities at age 60 for both partners to instrument retirement of both (exploiting the fact that the two partners typically differ a few years in age).

Finally, we cannot think of any other policy measure that would affect individuals of age 60 . Welfare, health insurance or unemployment benefits do not vary significantly at age 60 in France.

More formally, we model the effect of retirement of both partners on their joint and separate (disjoint) leisure hours as follows. Let $\mathrm{R}$ be a dummy for retirement, equal to one if individuals have retired from market work and zero otherwise, and $\mathrm{L}$ be the hours of leisure. The subscript $\mathrm{m}$ stands for male partner and $\mathrm{f}$, for female partner, while $\mathrm{j}$ is 'joint' leisure or together; thus $\mathrm{L}_{\mathrm{m}}$ stands for disjoint leisure hours of the husband, $\mathrm{L}_{\mathrm{f}}$ for disjoint leisure hours of the wife, and $\mathrm{L}_{\mathrm{j}}$ for leisure hours together. Alternatively, we shall use four alternative definitions of leisure together, to check the robustness of the results (see Section 3.2 for more details of these definitions).

\footnotetext{
${ }^{1}$ See, for example, Blanchet, Didier and Louis-Paul Pele (1997) and Bozio, Antoine (2004) for more details of the French pension system.
} 
a)

$$
\mathrm{L}_{\mathrm{m}}=\mathrm{Z}_{\mathrm{m}} \beta^{\mathrm{lm}}+\mathrm{Z}_{\mathrm{f}} \beta^{\mathrm{lf}}+\mathrm{W} \omega^{\mathrm{lm}}+\mathrm{R}_{\mathrm{m}} \gamma^{\mathrm{lm}}+\mathrm{R}_{\mathrm{f}} \gamma^{\mathrm{lf}}+\operatorname{Agepol}_{\mathrm{m}} \psi^{\mathrm{lm}}+\operatorname{Agepol}_{\mathrm{f}} \psi^{\mathrm{lf}}+v^{\mathrm{lm}}
$$

b)

$$
\mathrm{L}_{\mathrm{f}}=\mathrm{Z}_{\mathrm{m}} \lambda^{\mathrm{lm}}+\mathrm{Z}_{\mathrm{if}} \lambda^{\mathrm{lf}}+\mathrm{W} \omega^{\mathrm{lf}}+\mathrm{R}_{\mathrm{m}} \delta^{\mathrm{lm}}+\mathrm{R}_{\mathrm{f}} \delta^{\mathrm{lf}}+\operatorname{Agepol}_{\mathrm{m}} \zeta^{\mathrm{lm}}+\operatorname{Agepol}_{\mathrm{f}} \zeta^{\mathrm{lf}}+v^{\mathrm{lf}}
$$

c)

$$
\mathrm{L}_{\mathrm{j}}=\mathrm{Z}_{\mathrm{m}} \lambda^{\mathrm{ljm}}+\mathrm{Z}_{\mathrm{if}} \lambda^{\mathrm{ljf}}+\mathrm{W} \omega^{\mathrm{lj}}+\mathrm{R}_{\mathrm{m}} \delta^{\mathrm{ljm}}+\mathrm{R}_{\mathrm{f}} \delta^{\mathrm{ljf}}+\operatorname{Agepol}_{\mathrm{m}} \zeta^{\mathrm{ljm}}+\text { Agepol }_{\mathrm{f}} \zeta^{\mathrm{ljf}}+v^{\mathrm{lj}}
$$

d)

$$
\mathrm{R}_{\mathrm{im}}{ }^{*}=\mathrm{Z}_{\mathrm{m}} \beta^{\mathrm{rm}}+\mathrm{Z}_{\mathrm{f}} \beta^{\mathrm{rf}}+\mathrm{D}_{\mathrm{m}} \gamma^{\mathrm{rm}}+\operatorname{Age}_{\mathrm{m}} \mathrm{D}_{\mathrm{m}} \eta^{\mathrm{rm}}+\operatorname{Age}_{\mathrm{m}}\left(1-\mathrm{D}_{\mathrm{m}}\right) \pi^{\mathrm{rm}}+\mathrm{D}_{\mathrm{f}} \gamma^{\mathrm{rf}}+
$$$$
+\operatorname{Age}_{\mathrm{f}} \mathrm{D}_{\mathrm{f}} \eta^{\mathrm{rf}}+\operatorname{Age}_{\mathrm{f}}\left(1-\mathrm{D}_{\mathrm{f}}\right) \pi^{\mathrm{rf}}+v^{\mathrm{rm}} ; \mathrm{R}_{\mathrm{im}}=1 \text { if } \mathrm{R}_{\mathrm{im}}{ }^{*}>0 \text { and } \mathrm{R}_{\mathrm{im}}=0 \text { if } \mathrm{R}_{\mathrm{im}}{ }^{*} \leq 0
$$

e)

$$
\mathrm{R}_{\mathrm{if}}{ }^{*}=\mathrm{Z}_{\mathrm{m}} \lambda^{\mathrm{rm}}+\mathrm{Z}_{\mathrm{f}} \lambda^{\mathrm{rf}}+\mathrm{D}_{\mathrm{m}} \delta^{\mathrm{rm}}+\operatorname{Age}_{\mathrm{m}} \mathrm{D}_{\mathrm{m}} \tau^{\mathrm{rm}}+\operatorname{Age}_{\mathrm{m}}\left(1-\mathrm{D}_{\mathrm{m}}\right) \mu^{\mathrm{rm}}+\mathrm{D}_{\mathrm{f}} \delta^{\mathrm{rf}}+
$$

+ Age $_{\mathrm{f}} \mathrm{D}_{\mathrm{f}} \tau^{\mathrm{rf}}+\operatorname{Age}_{\mathrm{f}}\left(1-\mathrm{D}_{\mathrm{f}}\right) \mu^{\mathrm{rf}}+v^{\mathrm{rf}} ; \mathrm{R}_{\mathrm{if}}=1$ if $\mathrm{R}_{\mathrm{if}}{ }^{*}>0$ and $\mathrm{R}_{\mathrm{if}}=0$ if $\mathrm{R}_{\mathrm{if}}{ }^{*} \leq 0$

Here Age $_{m}=\left[\left(\right.\right.$ Age $\left.\left._{m}-60\right),\left(\text { Age }_{m}-60\right)^{2}, \ldots,\left(\text { Age }_{m}-60\right)^{\mathrm{n}}\right]$

$$
\begin{aligned}
& \text { Age }_{\mathrm{f}}=\left[\left(\text { Age }_{\mathrm{f}}-60\right),\left(\text { Age }_{\mathrm{f}}-60\right)^{2}, \ldots,\left(\text { Age }_{\mathrm{f}}-60\right)^{\mathrm{n}}\right] \\
& \text { Agepol }_{\mathrm{m}}=\left[\left(\text { Age }_{\mathrm{m}}-60\right),\left(\text { Age }_{\mathrm{m}}-60\right)^{2}, \ldots .,\left(\text { Age }_{\mathrm{m}}-60\right)^{\mathrm{n}}\right] \\
& \text { Agepol }_{\mathrm{f}}=\left[\left(\text { Age }_{\mathrm{f}}-60\right),\left(\text { Age }_{\mathrm{f}}-60\right)^{2}, \ldots,\left(\text { Age }_{\mathrm{f}}-60\right)^{\mathrm{n}}\right]
\end{aligned}
$$

The vectors $Z_{m}$ and $Z_{f}$ contain completed education dummies; $W$ contains two dummies for whether the activity diary was collected on a weekend day or during the winter season; $D_{m}$ and $D_{f}$ are dummies for whether the two individuals have reached age 60 (here, 720 months of age); and Age is a polynomial of order $\mathrm{n}$ in age minus 60 ( 720 months), which is fully interacted in the retirement equations with the dummies for being 60 or older; and Agepol is a polynomial of order $\mathrm{n}$ in age minus 60 . The Greek letters denote vectors of coefficients. The v's are normally distributed errors, independent of $\mathrm{W}, \mathrm{Z}_{\mathrm{m}}$ and $\mathrm{Z}_{\mathrm{f}}$ and the ages of both partners. The equations for retirement therefore are probit type equations; the hours of leisure equations are linear (demand) equations.

The equations for retirement status, equations d) and e), explain retirement of each partner from the control variables of both partners, flexible continuous functions of each partner's age, and dummies $D_{m}$ and $D_{f}$ for whether the two individuals have reached age 60 (i.e. 720 months of age). The coefficients on the dummies determine the discontinuities at age 60 of the individual and the partner; we expect the former to be larger than the latter, but if there is joint retirement (in the sense that the preference for retirement of one spouse increases if the other spouse is retired), the individual's retirement decision may also depend on whether the partner is age eligible for retirement. 
The five equations will be estimated jointly with simulated maximum likelihood. The error terms in the five equations are allowed to be correlated with each other. In this model, own and partner's retirement are allowed to be endogenous to leisure choices. The dummies $D_{m}$ and $D_{f}$ are included in the retirement equations but excluded from the leisure equations: the probability to be retired changes discontinuously when reaching age 60 (and perhaps also when the spouse reaches age 60), but given retirement status, leisure is assumed to be a continuous function of age. This makes our approach essentially a double regression discontinuity approach. Finally, the weekend and winter season dummies are entered in the leisure equations as individuals usually enjoy more leisure at weekends and perhaps less on winter days. In some specifications we also interact the partners' retirement dummies with the weekend dummy, as retirement typically will free more time during week days than at weekends -weekend work was not very common in France at the time of our survey.

If the retirement decision is exogenous to the leisure choices, it would not be necessary to rely on regression discontinuity for identification. To test the sensitivity of our results to allowing for endogenous retirement, we also estimate the same leisure equations taking retirement as an exogenous variable (that is, not jointly with retirement equations) and compare the estimated effects of retirement on leisure.

\section{The data: sample selection and covariates}

The data for the analysis are drawn from the 1998-99 French time use survey, carried out by the National Statistical offices (INSEE). This survey is a representative sample of more than 8,000 French households. Three questionnaires were collected: a household questionnaire, an individual questionnaire and an activities diary. The diary was collected for both adults in the household, which is an advantage over many other surveys that only have information on one individual in each household. The diary was filled in for one day, which was chosen by the interviewer and could be either a week day or a weekend day. This was the same day for all household members.

\subsection{Sample selection}

Selected couples, married or unmarried but living together, gave a sample of 5,287 couples with and without children -dropping also the one same sex couple. We then applied the following criteria to select estimation samples of older men and women in a couple.

1. Each respondent was aged 50 to 70 . 
2. Each respondent had filled in the diary.

3. No respondent had filled in the diary on an atypical day, defined as a special occasion such as a vacation day, a day of a wedding or a funeral, a sick leave day.

4. Male respondents were not unemployed or other inactive.

5. We dropped one man who reported to be a home-maker, but we kept housewives.

Applying these criteria led to a sample of 1043 couples. The first criterion sets bounds of ten years (120 months) on each side of the discontinuity. To check for the robustness of our results to different sample cuts, we also experiment with different age cuts for the sample. The fourth criteria is imposed only for men as many women in our sample are housewives (against only one man) and thus we felt that we would have a very selected sample if we included only dual-earners or retirees from work. Besides, the sample side drops dramatically if we drop couples with an inactive wife.

\subsection{Leisure, age, retirement, and covariates}

Our definition of leisure includes socializing, eating, doing sports, playing video-games, watching the television, playing with computer, reading, going to the cinema or the theatre, hiking, walking, fishing, hunting. In total, it includes some forty-five activities.

This measure of 'leisure' corresponds to what Aguiar and Hurst (2007), for example, define as "narrow' leisure. Broader measures include any time off work, such as also notably house work and sleep. Here we do not count house work since house work is not considered enjoyable by many. We also ignore sleep as closer to 'biological' time than leisure. Our aim is to capture complementarities in leisure and, therefore, we focus on activities that are considered as "pure" leisure, which is enjoyable time.

We use four different definitions of leisure hours together as follows:

a) Our first definition of joint leisure requires the two partners to have reported exactly the same leisure activity (out of the over 45 possible activities considered as leisure here) during the same time interval and also that they both reported that they did this activity with 'each other'. To this end, we use here the question "with whom", which allows for four possible answers: family, friends, neighbors, and other people. We require that both partners say "with family". 
b) The second definition of joint leisure requires that the two partners have reported exactly the same leisure activity during the same time interval and also that both reported that they did this activity in the same place. There are four possible locations defined for each activity in the diary: at home; at work; outside; and somewhere else.

c) Our third definition of joint leisure includes exactly the same leisure activities carried out by the partners on the same time interval. Here we do not require that the activity was carried out with family or in the same place.

d) Finally, the last definition includes any leisure activities carried out by the partners on the same time interval and at the same place. This is the broadest definition we use. For example, it amounts to considering this to be joint leisure if the husband watches football and the wife reads a book and they are both at home.

These four definitions imply a decreasing degree of restrictiveness - the first being the narrowest and the last the broadest. Consequently, the hours of leisure of each partner that are not classified as joint leisure according to each of these definition, are then considered as hours of "disjoint" or separate leisure hours. It follows that we also have four different definitions of separate leisure hours of partners -one for each of the above four definitions of joint leisure (see Table 2).

In our data, age is available in months. We also know the exact day of the interview. And the employment or retirement status is derived from the respondent's self-assessed occupational status, also asked at the day of the interview. The indicator for retirement takes value one for respondents that reported to be retirees or early-retirees. In the analysis, housewives and other inactive women (these last are very few as most inactive women classify themselves as "housewives", which is somewhat understandable) will be considered together as nonemployed - as opposed to those still at work. This seems reasonable since we are interested in leisure complementarities and thus housewives have as much time available as retired women.

As far as the other covariates go, three education levels are distinguished: less than high school, high school, and college or more.

\subsection{Descriptive statistics}

Descriptive statistics for the samples are given in Table 1. About 57 per cent of the men and 43 of the women in a couple, in our sample, are aged 60 or above. The percentage employed is about the same for both partners; only slightly larger for men that are employed 36 per cent 
of the time against 32 per cent for women. In other words, with the sample selection described above, 64 per cent of the men and 68 per cent of the women are not engaged in gainful employment. The majority of individuals have less than high school (the benchmark). Men tend to be slightly more educated than women: 12 (10) per cent of husbands (wives) have completed high school and 15 (11) per cent have college or more education.

Descriptive statistics of participation, mean and median diary day duration, in minutes, for market work and leisure are given in Table 2. First of all, it is remarkable that almost all individuals in the couple sample participate in leisure separately and 'together'. About 99 percent of the sample participates in separate leisure activities. Depending on the definition of joint leisure adopted, between 94 and 98 percent of the sample spends some leisure together.

Interestingly, going from the narrowest to the broadest of our definitions of joint leisure, joint leisure hours increase progressively, and separate leisure hours fall (as it should). Under the narrowest of our joint leisure definitions (see Section 3.2), we find that on a typical diary day the husband enjoys five hours of separate leisure activities on average and the wife a little less than four hours; while almost two hours and a half are spent, on average, on leisure activities done together. Using the broadest joint leisure measure, almost four hours are spent, on average, on leisure activities together.

Generally, we find that older partners tend to spend more leisure hours on their own than together. This is line with the earlier literature on leisure hours of dual-earners which found that partners actually tend to spend only a quite small fraction of their leisure hours together (Hallberg, 2003).

\section{Exploratory graphical analysis}

We carry out some exploratory graphical analysis of the discontinuities in, respectively, retirement or leisure hours upon reaching age 60 and above for each partner. In line with the regression discontinuity literature (see Lee and Lemieux, 2010; Wilbert van der Klaauw, 2008; and Imbens and Lemieux, 2007, for an account), we first inspect graphically the expected jump at the point of discontinuity (age 60 here or, more precisely, 720 months since month and year of birth) in the assignment variable (age) for the treatment (retirement) and 
the outcome variable (leisure), using kernel smoothed polynomials in age from the right and the left of the cutoff. We also draw 95 per cent confidence bounds around each curve.

Individual retirement status is plotted against age to inspect jumps in the retirement probability at age 60 (720 months) and above in Charts 1 . There is an obvious discontinuity at the age cutoff of 60 for both men and women in a couple. The confidence bands never cross the curves suggesting that the jumps are statistically significant.

Jumps at age 60 are also apparent in joint leisure hours of partners under all definitions of joint leisure considered (Charts 2 and 3), though the jumps in joint leisure are less pronounced than those in retirement. Discontinuities in disjoint (separate) leisure hours of partners at age 60 are large and especially so for the husband (Chart 4).

Next to this, we carry out some more parametric analysis of the discontinuities at age 60 in the retirement probability of men and women in a couple. We estimate probit models of retirement, respectively, for men and women in a couple, separately and jointly, and including and excluding the education dummies. We select a specification with cubic polynomials in age, as the cubic term shows up significant for husbands; while when using a quartic polynomial, quartic terms are not significant for either partner. The estimated coefficient on the cutoff dummy is statistically significant for both partners under all specifications (see Table 3). Marginal estimates (see Table 4) suggests that the retirement probability increases by 0.32 for men in a couple aged 60 and above; and by 0.20 for women in a couple aged 60 and above. However, whether the partner is above the age cutoff has no significant effect on own retirement. Stancanelli (2012) replicates this approach using thirteen years of French Labor Force Statistics pooled together, giving a sample of over two-hundred thousand couples, and also concludes that the partner being age 60 and above has no significant effect on own retirement.

As far as education goes, college education delays retirement as plausible, since this also delays entry into the labour market and, with that, also accumulation of pension rights.

To sum up we find supporting evidence of our identification strategy based on discontinuities in the retirement probability of each partner at age 60 . 


\section{Estimation results}

We have estimated simultaneous models of retirement and leisure of partners by simulated maximum likelihood, using 100 draws. $^{2}$ The explanatory variables of the retirement equations include dummies for age 60 (that is to say, 720 months of age) and older, and left and right cubic polynomials in months of age of the two partners interacted with the age 60 (720 months of age) dummies (see Section 2). The coefficients on the dummies determine the discontinuities at age 60 of the individual and the partner. The other regressors included in the retirement equations are indicators for whether each partner has completed high school or college. The joint and disjoint (own) leisure equations include the same control variables and a flexible cubic ${ }^{3}$ polynomial in age, and add the retirement status dummies of both partners and weekend and winter diary dummies as additional regressors. The error terms of the equations of the system are assumed to be jointly normally distributed and we also estimate their unrestricted correlations.

First of all, we present results of estimation of the model of the effect of retirement on joint and own (disjoint) leisure time of partners, using the narrowest of our definitions, which requires partners to carry out exactly the same leisure activity during the same interval of time and to report that they did this with family (see Table 5). We show all the estimates except for the coefficients on the age polynomials interacted with the dummies for age 60 and above in the retirement equations (as these are shown for the first stage regressions in Table 3 ) and the constant terms. The estimated correlations across the equations of the system are given in Table 6. Results of estimation of the joint leisure model under the assumption that retirement decisions are exogenous (dropping the retirement equations) are provided in Table 7.

We conclude that own retirement increases significantly and very largely husband's disjoint leisure hours, by about 4 hours. The wife's retirement has no significant effect on her separate leisure. We also find that the effect of retirement of the husband on joint leisure hours is negative, while retirement of the wife has the expected positive sign and it is more than twice as large as the negative effect of the husband's retirement.

As far as the education covariates go, college increases separate leisure of both husband and wife but it has no effect on joint leisure hours. For women, college education of the husband raises their separate leisure further.

\footnotetext{
${ }^{2}$ See Roodman, 2007 and 2009, for details of the procedure that we used.

${ }^{3}$ Using higher order polynomials does not affect the conclusions.
} 
The correlations in the unobservables of the retirement equations of partners are strongly significant and positive (see Table 6). On the contrary, the unobservables of the disjoint leisure equation of each partner are strongly negatively correlated with own retirement, while they are strongly positively correlated with each other. Furthermore, the unobservables of joint leisure time are strongly negatively correlated with the retirement equations of the wife and positively with that of the husband, suggesting some intriguing patterns that would reinforce the asymmetries observed. Therefore, endogenizing the retirement decision, retirement of the husband reduces joint leisure time of the partners but there are unobservables driving his retirement decision and the leisure time together of partners that are positively correlated. The opposite is true for the wife: her retirement increases joint leisure time of the partners but there are unobservables driving her retirement decision and the leisure time together of partners that are negatively correlated. This may possibly be explained by the order of retirement, as husbands are on average older, as we already said. These asymmetries in partners' retirement decisions and leisure time together are also in line with the conclusions in Stancanelli and van Soest (2012) who found that while partner's retirement increases own hour of home production, the cross-effect of the wife's retirement on the husband's home production hours is significantly negative. They also match well with the conclusions of the structural model of joint retirement of partners put forward by Gustman and Steinmeier (2009), who argue that in some cases individuals in a couple may decide to retire only if their partner does not retire and find, for the USA, that the increased labour force participation of women has actually contributed to lower husbands' hours of market work.

Remarkably, results of estimation of the models without allowing for endogeneity of partners' retirement decision (see Table 7) would lead us to conclude that retirement of either partner has a strongly significant and positive effect on joint leisure hours, thus hiding all of the asymmetries.

To look further into this asymmetry of responses of joint leisure to partners' retirement we allow the effect of retirement on leisure hours to differ across week and weekend days (see Table 8), exploiting the information on the day of collection of the time diary -recall that the diary was collected on the same day for all household members, which was chosen by the interviewer, and that we discarded atypical days (see Section 3 for more details). Then we find that his retirement reduces joint leisure both on week days (by about 45 minutes on average) and on a weekend day (by 53 minutes), though these effect are weakly significant statistically. Her retirement increases joint leisure by two hours and a half on a week day and 
by over two hours on a weekend. The husband's disjoint leisure increases by over four hours on a week day and by over two hours on a weekend. The husband retirement also increases her separate leisure by over an hour on a weekend while her retirement has no effect on her separate leisure.

Next, Table 9 presents results of estimation of the model as in Table 8 including additional controls for whether partners are both retired. We also include cross-effects of the dummies for age 60 and above of the partners in the retirement equations (though these turn out not significant statistically). Under this specification, again we find positive effects of the husband's retirement on his own leisure on week days and weekends and negative effects on joint leisure at weekends. His retirement also raises her separate leisure, though this effect is significant only for weekdays and only at the ten percent significance level. We also find significant negative cross-effects of retirement of the wife on the husband's separate leisure hours both on week and weekend days. Furthermore, her retirement affects negatively also her separate leisure on weekends (and the coefficient for weekdays is also negative though not significant). Joint leisure hours increase significantly with her retirement and this is true for both week and weekend days. Finally, when both partners are retired, joint leisure together increases by an extra forty-five minutes on a week day while her separate leisure hours fall by almost an hour on week days.

Finally, Table 10 presents results of estimation of the same model as in Table 5 for our alternative definitions of joint leisure. Interestingly, the negative effect of the husband retirement on leisure hours together becomes not significant statistically using broader definitions of joint leisure and the sign of the coefficient turns into positive under some of the alternative definitions (though not significant). The positive effect of her retirement on joint leisure together is strongly significant under all definitions of joint leisure adopted here and this coefficient increases in size using broader joint leisure definitions -as reasonable since the broader the definition the more the hours of leisure defined as 'joint' leisure. This also explains why the negative effect of the husband's retirement on joint leisure "washes up" adopting broader joint leisure definitions.

As an alternative robustness check, we restricted the sample bounds on the two sides of the discontinuity cutoff, selecting, respectively, partners both aged 52 to 68 included (Table 11), 53 to 67 (Table 12) and 54 to 66 (Table 13). Under all these specifications, our findings are validated. The age 60 and above dummies are statistically significant for both partners. 
Retirement of the husband has a negative effect on joint leisure and a positive one on the separate leisure hours of the husband. Retirement of the wife raises joint leisure of partners. Interestingly, the positive effect of her retirement on her separate leisure becomes significant using these smaller sample cuts.

\section{Conclusions}

In the scant literature on partners' joint retirement decisions one of the explanations for joint retirement is externalities in leisure. However, recent work also points to asymmetries in partners' retirement decisions. Earlier studies of joint retirement did not explicitly consider the extent to which partners spend their leisure time together.

In this study, we use diary data on leisure activities of older French partners to investigate the causal effect of individual and partner's retirement on the leisure hours that the two partners spend together or separately, which is a measure of leisure complementarities. Our identification strategy exploits the fact that for many French workers, the earliest age at which a retirement pension can be drawn is age 60 , which enables us to use a fuzzy regression discontinuity approach to identify the effect of both partners' retirement on leisure.

The data for the analysis are drawn from a French time use survey which not only collects a diary for both partners on the same day but also asks questions as regards 'with whom' and 'where' time was spent. Therefore, we can construct four alternative measures of leisure hours spent together by partners.

We estimate a five simultaneous equations system of partners' retirement and leisure hours, including two equations for retirement and three for leisure hours -of each partner on his own and together. We find that the retirement probability increases significantly for spouses aged 60 and above, which supports our identification strategy. We conclude that although retirement increases the hours each partner allocates to leisure activities, only retirement of the wife increases significantly leisure hours together. The retirement of the husband has either no effect or a negative one, overall. These findings are robust to various alternative definitions of joint leisure and different sample cuts, allowing for smaller bounds on the two sides of the discontinuity cut-offs. They are also quite robust to the inclusion of additional controls for retirement of both partners. 
Remarkably, results of estimation of the models without controlling for endogeneity of partners' retirement decision would lead one to conclude that retirement of either partner has a strongly significant and positive effect on joint leisure hours of partners, thus concealing all of the asymmetries. Therefore, not controlling for selection into retirement would produce the results a priori anticipated in the literature; while controlling for selection into retirement elicits asymmetries in leisure choices of partners after retirement. These asymmetries are well in line with the conclusions of recent joint retirement literature. Overall, our findings suggest that leisure complementarities may not be the main engine of joint retirement as leisure hours together tends to increase with the wife retirement but do not respond to the husband's retirement.

\section{References}

Mark Aguiar and Erik Hurst, 2007, Measuring Trends in Leisure: The Allocation of Time over Five Decades, The Quarterly Journal of Economics, MIT Press, 122(3), 969-1006.

Battistin, Erich, Agar Brugiavini, Enrico Rettore and Guglielmo Weber (2009), The Retirement Consumption Puzzle: Evidence from a Regression Discontinuity Approach American Economic Review, 99(5), 2209-2226.

Blanchet, Didier and Louis-Paul Pele (1997), Social Security and Retirement in France, NBER Working Paper No. 6214.

Bozio, Antoine (2004), "Does Increasing Contribution Length Lead to Higher Retirement Age? Evidence from the 1993 French Pension Reform”, mimeo.

Card, David, Carlos Dobkin and Nicole Maestas (2009), Does Medicare Save Lives?, Quarterly Journal of Economics, 124(2), 597-636.

Card, David, Carlos Dobkin and Nicole Maestas (2004), The Impact of Nearly Universal Insurance Coverage on Health Care Utilization and Health: Evidence from Medicare, NBER Working Paper 10365.

Casanova, Maria (2010), "Happy Together: a structural model of couples' joint retirement choices", mimeo.

Gustman, Alan and Thomas Steinmeier (2009), Integrating Retirement Models, NBER Working Paper 15607.

Gustman, Alan and Thomas Steinmeier (2000), Retirement in Dual-Career Families: A Structural Model, Journal of Labor Economics, 18, 503-545.

Hallberg, Daniel (2003), Synchronous Leisure, Jointness and Household Labor Supply, Labour Economics, 10(2), 185-203. 
Hamermesh, Daniel S. (2000), Togetherness: Spouses' Synchronous Leisure, and the Impact of Children, NBER Working Papers 7455.

Hamermesh, Daniel S. (2002), Timing, Togetherness and Time Windfalls, Journal of Population Economics, 15(4), 601-623.

Hurd, Michael (1990), The Joint Retirement Decision of Husbands and Wives, in: Issues in the Economics of Aging, David Wise (ed.), NBER, pp. 231-258.

Lundberg, S., R. Startz and S. Stillman (2003), The Retirement-Consumption Puzzle: A Marital Bargaining Approach, Journal of Public Economics, 87(5-6), 1199-1218.

Imbens, Guido and Thomas Lemieux (2007), Regression Discontinuity Design: a Guide to Practice, Journal of Econometrics, 142, 615-635.

Van der Klaauw, Wilbert (2008), Regression-Discontinuity Analysis: A Survey of Recent Developments in Economics, Labour, 22(2), 219-245.

Van der Klaauw, Wilbert (2002), Estimating the Effect of Financial Aid Offers on College Enrollment: A Regression-Discontinuity Approach, International Economic Review, 43(4), 1249-1287.

Lee, David S. and Thomas Lemieux (2010), Regression Discontinuity Designs in Economics, Journal of Economic Literature, 48(2), 281-355.

Robinson, John and Geoffrey Godbey (1997), Time for Life: The Surprising Way Americans Spend Their Time, University Park, The Pennsylvania State University Press.

Roodman, David (2009), Estimating Fully Observed Recursive Mixed-Process Models with CMP. Working Papers 168, Center for Global Development.

Roodman, David (2007), CMP: Stata Module to Implement Conditional (Recursive) Mixed Process Estimator. Statistical Software Components S456882, Boston College Department of Economics, revised 22 May 2009.

Sayer, Liana, Suzanne Bianchi and John Robinson (2001), Time Use Patterns of Older Americans, Report to NIA, University of Maryland.

Stancanelli, Elena and Arthur Van Soest (2012), Retirement and Home Production: A Regression Discontinuity approach, American Economic Review, Papers and Proceedings, May 2012.

Stancanelli, Elena (2012), “Joint Retirement”, mimeo. 
Table 1. Sample descriptives

\begin{tabular}{|l|l|l|l|l|}
\hline & \multicolumn{2}{|l|}{ Male partner } & Female partner \\
\hline & Mean & standard deviation & Mean & standard deviation \\
\hline Age (in years) & 60.72 & 5.50 & 58.60 & 5.61 \\
\hline $\begin{array}{l}\text { Age 60 or older, } \\
\text { dummy }\end{array}$ & 0.57 & 0.49 & 0.43 & 0.47 \\
\hline Retired & 0.64 & 0.48 & 0.67 & 0.47 \\
\hline Employed & 0.36 & 0.48 & 0.32 & 0.47 \\
\hline Born in France & 0.96 & 0.18 & 0.97 & 0.16 \\
\hline $\begin{array}{l}\text { High School (12 years } \\
\text { schooling) }\end{array}$ & 0.12 & 0.32 & 0.10 & 0.30 \\
\hline College and more & 0.15 & 0.36 & 0.11 & 0.31 \\
\hline & & & & \\
\hline & & Household characteristics & \\
\hline & & Mean & standard deviation & \\
\hline $\begin{array}{l}\text { Number of children at } \\
\text { home }\end{array}$ & & 0.15 & 0.51 & \\
\hline Cohabiting & & 0.04 & 0.19 & \\
\hline $\begin{array}{l}\text { Regional } \\
\text { Unemployment rate }\end{array}$ & & 11.45 & 2.46 & \\
\hline Weekend time diary & & 0.23 & 0.42 & \\
\hline Winter season diary & & 0.25 & 0.42 & \\
\hline & & 1043 & & \\
\hline Observations & & & & \\
\hline Note: These variables as well as the sample selection steps are detailed in Section 3 of the paper. \\
\hline
\end{tabular}


Table 2. Participation rate and mean duration of market work and leisure

\begin{tabular}{|c|c|c|c|c|c|c|}
\hline & \multicolumn{3}{|l|}{ Male partner } & \multicolumn{3}{|c|}{ Female partner } \\
\hline & $\begin{array}{l}\text { Participation } \\
\text { rate } \%\end{array}$ & $\begin{array}{l}\text { Mean } \\
\text { duration (st. } \\
\text { dev.) }\end{array}$ & $\begin{array}{l}\text { Median } \\
\text { duration }\end{array}$ & $\begin{array}{l}\text { Participation } \\
\text { rate } \%\end{array}$ & $\begin{array}{l}\text { Mean } \\
\text { duration (st. } \\
\text { dev.) }\end{array}$ & $\begin{array}{l}\text { Median } \\
\text { duration }\end{array}$ \\
\hline $\begin{array}{l}\text { Market work, } \\
\text { standard } \\
\text { question }\end{array}$ & 24.74 & $\begin{array}{l}112.01 \\
(199.20)\end{array}$ & 0 & 25.02 & $\begin{array}{l}94.15 \\
(176.93)\end{array}$ & 0 \\
\hline $\begin{array}{l}\text { Market work, } \\
\text { diary }\end{array}$ & 29.82 & $\begin{array}{l}137.83 \\
(235.46)\end{array}$ & 0 & 21.67 & $\begin{array}{l}86.04 \\
(182.88)\end{array}$ & 0 \\
\hline $\begin{array}{l}\text { Joint Leisure } \\
\text { (a) }\end{array}$ & 93.77 & $\begin{array}{l}159.79 \\
(117.22)\end{array}$ & 140 & 93.77 & $\begin{array}{l}159.79 \\
(117.22)\end{array}$ & 140 \\
\hline $\begin{array}{l}\text { Joint Leisure } \\
\text { (b) }\end{array}$ & 96.26 & $\begin{array}{l}195.47 \\
(130.90)\end{array}$ & 180 & 96.26 & $\begin{array}{l}195.47 \\
(130.90)\end{array}$ & 180 \\
\hline $\begin{array}{l}\text { Joint Leisure } \\
\text { (c) }\end{array}$ & 97.60 & $\begin{array}{l}215.88 \\
(136.31)\end{array}$ & 200 & 97.60 & $\begin{array}{l}215.88 \\
(136.31)\end{array}$ & 200 \\
\hline $\begin{array}{l}\text { Joint Leisure } \\
\text { (d) }\end{array}$ & 97.99 & $\begin{array}{l}237.96 \\
(141.89)\end{array}$ & 230 & 97.99 & $\begin{array}{l}237.96 \\
(141.89)\end{array}$ & 230 \\
\hline $\begin{array}{l}\text { Disjoint } \\
\text { Leisure (a) }\end{array}$ & 99.42 & $\begin{array}{l}302.42 \\
(177.33)\end{array}$ & 270 & 97.60 & $\begin{array}{l}228.24 \\
(144.02)\end{array}$ & 210 \\
\hline $\begin{array}{l}\text { Disjoint leisure } \\
\text { (b) }\end{array}$ & 99.23 & 266.74 & 240 & 96.55 & $\begin{array}{l}192.55 \\
(128.28)\end{array}$ & 180 \\
\hline $\begin{array}{l}\text { Disjoint leisure } \\
\text { (c) }\end{array}$ & 99.04 & $\begin{array}{l}246.34 \\
(159.26)\end{array}$ & 220 & 96.26 & $\begin{array}{l}172.15 \\
(123.04)\end{array}$ & 150 \\
\hline $\begin{array}{l}\text { Disjoint leisure } \\
\text { (d) }\end{array}$ & 98.95 & $\begin{array}{l}224.26 \\
(146.56)\end{array}$ & 200 & 95.59 & $\begin{array}{l}150.07 \\
(112.82)\end{array}$ & 130 \\
\hline $\begin{array}{l}\text { Note: Activiti } \\
\text { Definition (a) } \\
\text { moment and } \\
\text { by the partners } \\
\text { same leisure a } \\
\text { any leisure act }\end{array}$ & $\begin{array}{l}\text { re measured } \\
\text { oint leisure it } \\
\text { "family". D } \\
\text { the same mo } \\
\text { ities carried } \\
\text { ies carried ou }\end{array}$ & $\begin{array}{l}\text { minutes per } \\
\text { ludes exactly } \\
\text { inition (b) of } \\
\text { nent and at th } \\
\text { ti by the partn }\end{array}$ & $\begin{array}{l}\text { Remem } \\
\text { ame lei } \\
\text { leisure } \\
\text { e place. } \\
n \text { the sa }\end{array}$ & $\begin{array}{l}\text { s are collecte } \\
\text { ities carried } \\
\text { xactly the sa } \\
\text { n (c) of join } \\
\text { nt. Definitio }\end{array}$ & $\begin{array}{l}\text { over week ar } \\
\text { t by the partn } \\
\text { e leisure acti } \\
\text { eisure include } \\
\text { (d) of joint le } \\
\text { he place. }\end{array}$ & $\begin{array}{l}\text { veekend days } \\
\text { on the same } \\
\text { es carried out } \\
\text { xactly the } \\
\text { re includes }\end{array}$ \\
\hline
\end{tabular}


Chart 1. Retirement probabilities of partners: Kernel smoothed polynomials in age
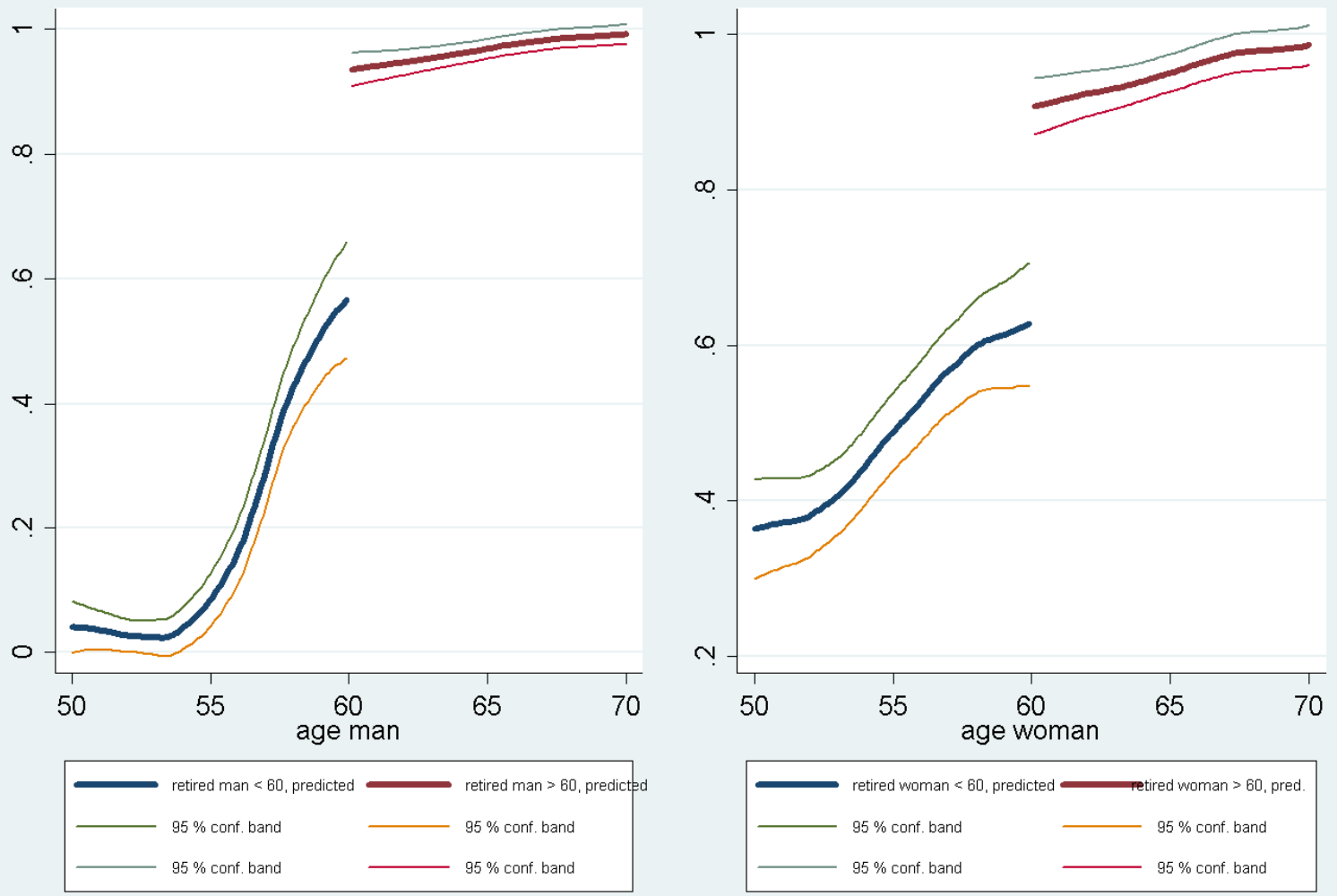
Chart 2. Leisure Together: Same Activity, Same Moment, with Family (a) or at the same Place (b) (Joint leisure minutes per day)
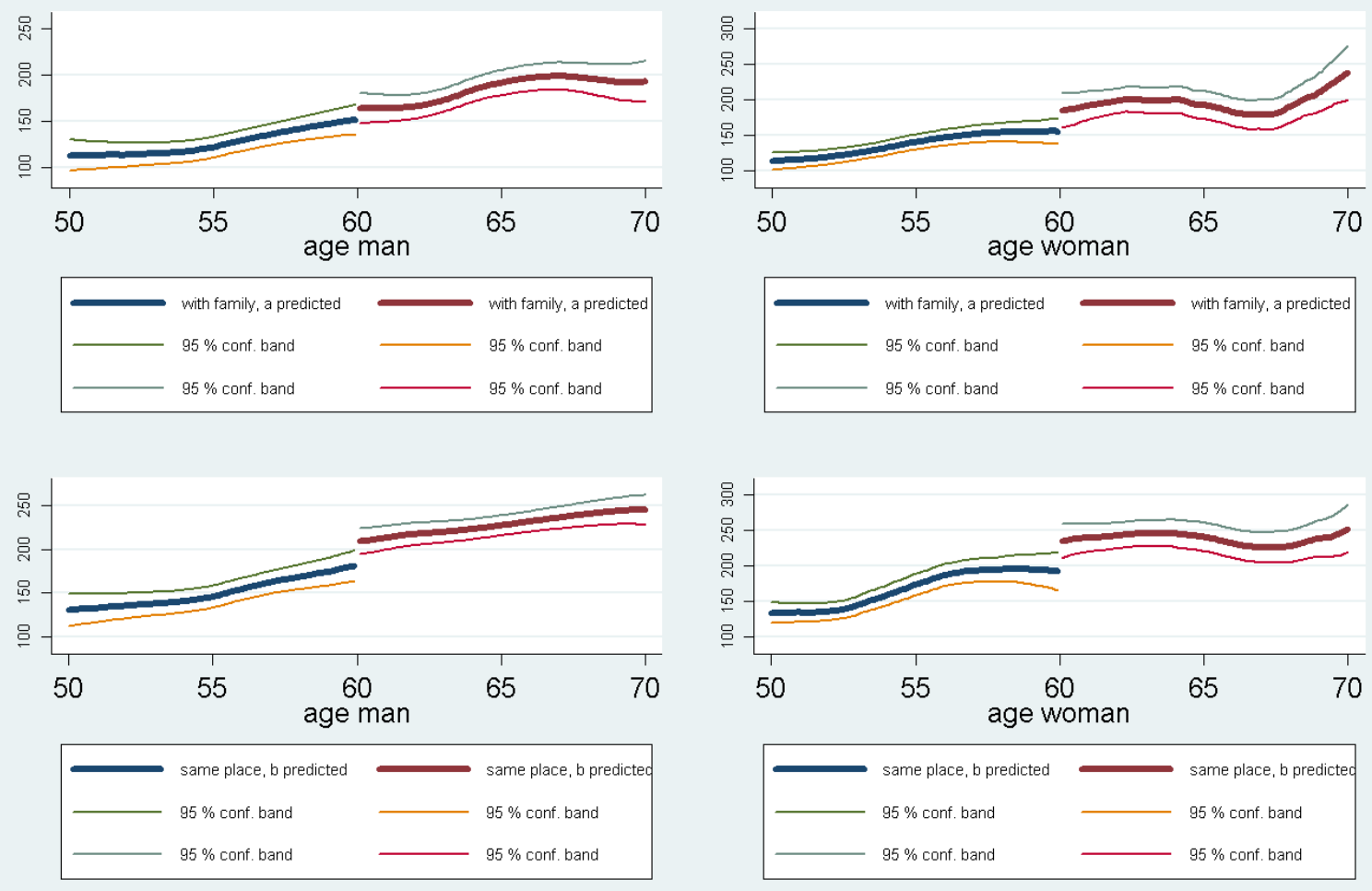

Chart 3. Leisure together: same moment same activity (c) or any activity at the same place (d) (Joint leisure minutes per day)
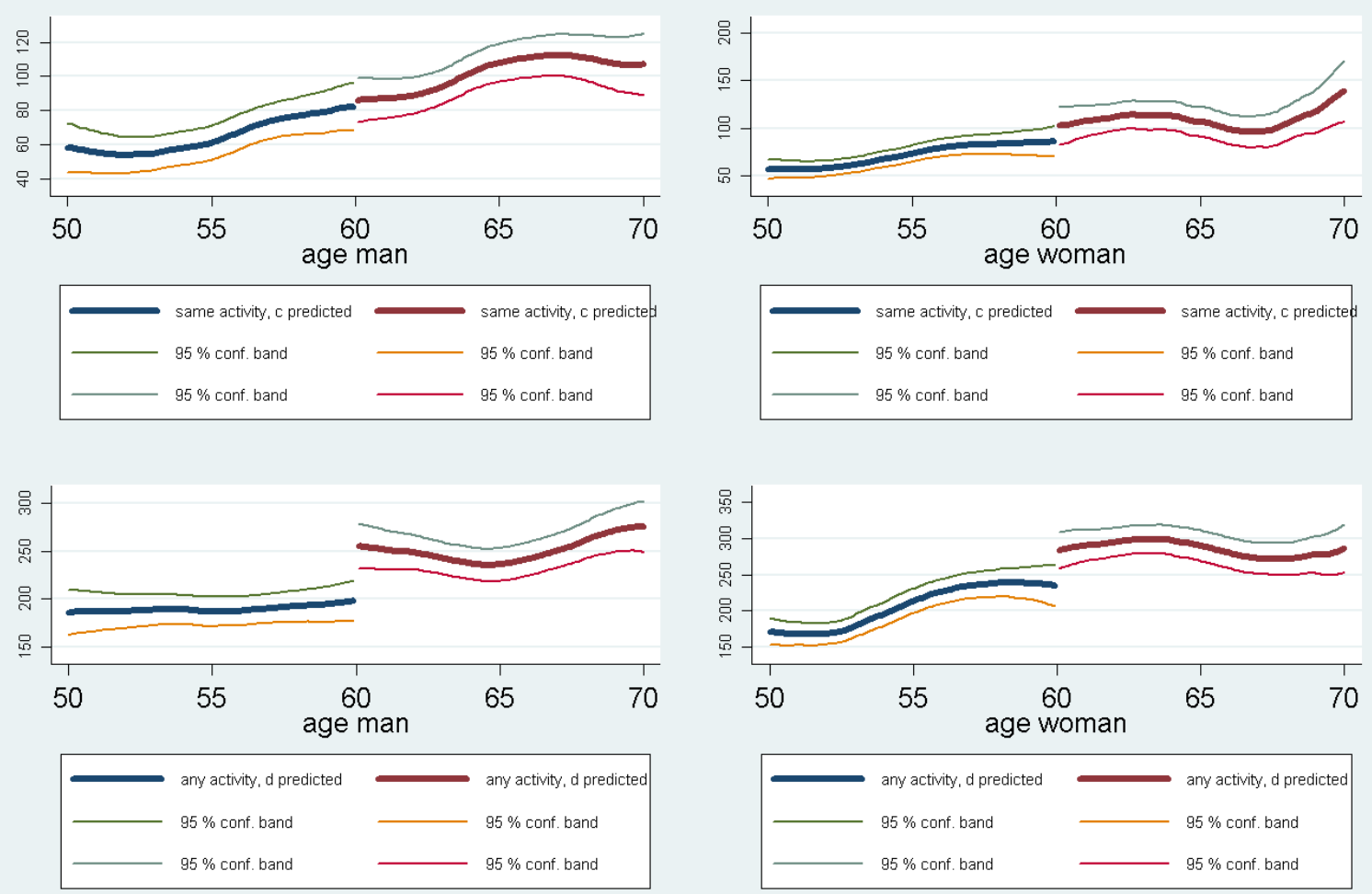
Chart 4. Separate leisure of partners: according to definition (a) or (d) (Separate leisure minutes per day)
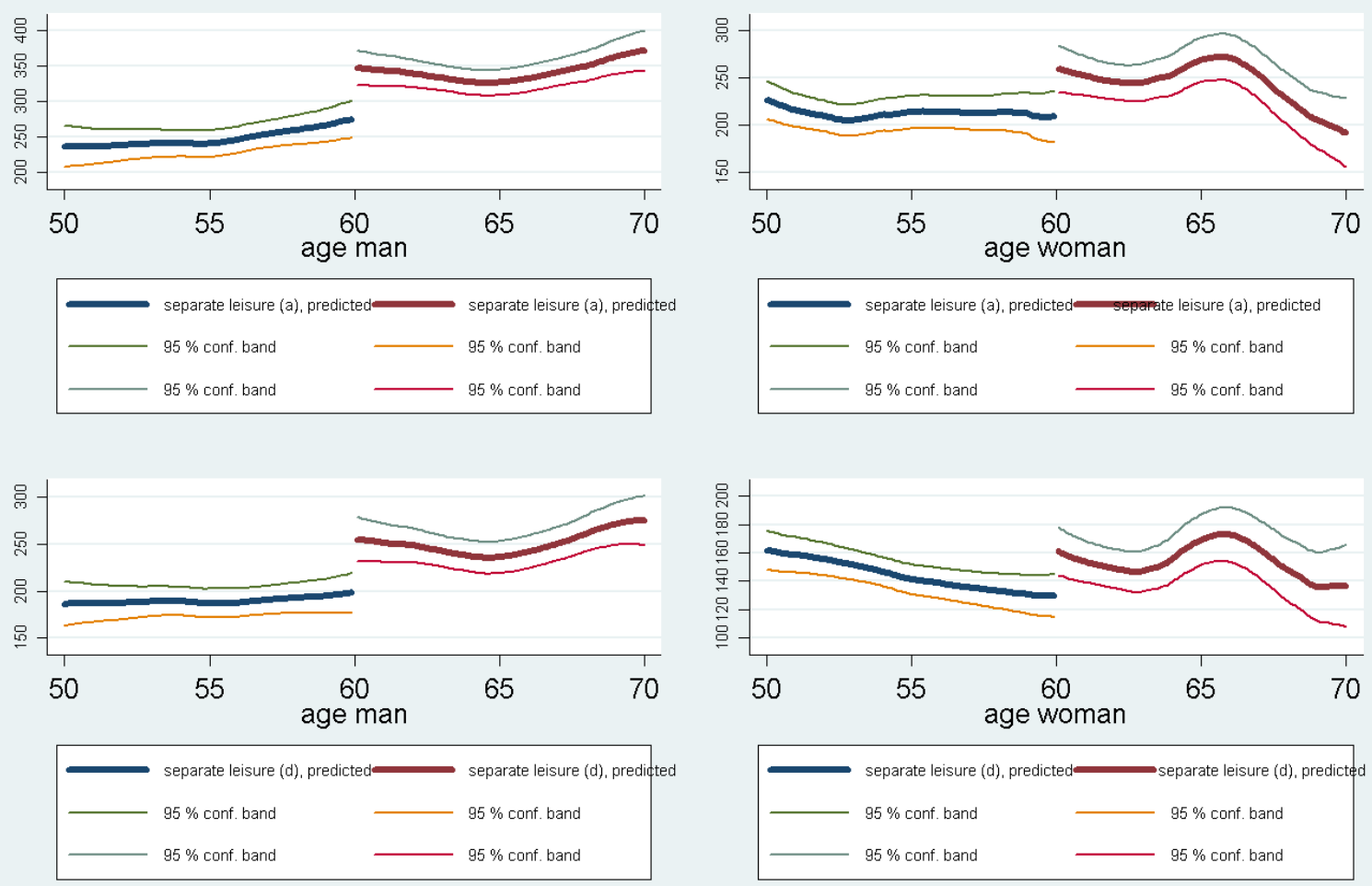


\begin{tabular}{|c|c|c|c|c|c|c|}
\hline \multirow[b]{3}{*}{ He is age $>=60\left(D_{m}\right)$} & $\mathrm{He}$ is retired & She is retired & He is retired & She is retired & $\mathrm{He}$ is retired & She is retired \\
\hline & & & \multicolumn{2}{|c|}{ Jointly Estimated } & \multicolumn{2}{|c|}{ Jointly Estimated } \\
\hline & $\begin{array}{l}0.760 * * \\
(0.378)\end{array}$ & & $\begin{array}{c}0.852 * * \\
(0.386)\end{array}$ & $\begin{array}{l}-0.157 \\
(0.346)\end{array}$ & $\begin{array}{l}0.999 * * \\
(0.392)\end{array}$ & $\begin{array}{c}-0.222 \\
(0.350)\end{array}$ \\
\hline$($ His Age -60$) * D_{m}$ & $\begin{array}{c}0.307 \\
(0.301)\end{array}$ & & $\begin{array}{c}0.281 \\
(0.309)\end{array}$ & $\begin{array}{c}0.104 \\
(0.228)\end{array}$ & $\begin{array}{c}0.284 \\
(0.315)\end{array}$ & $\begin{array}{c}0.171 \\
(0.231)\end{array}$ \\
\hline$(\text { His Age }-60)^{2 *} D_{m}$ & $\begin{array}{l}-0.0328 \\
(0.0823)\end{array}$ & & $\begin{array}{l}-0.0396 \\
(0.0854)\end{array}$ & $\begin{array}{l}-0.0123 \\
(0.0581)\end{array}$ & $\begin{array}{l}-0.0346 \\
(0.0866)\end{array}$ & $\begin{array}{l}-0.0282 \\
(0.0589)\end{array}$ \\
\hline$(\text { His Age }-60)^{3 *} D_{m}$ & $\begin{array}{c}0.00187 \\
(0.00608)\end{array}$ & & $\begin{array}{c}0.00267 \\
(0.00640)\end{array}$ & $\begin{array}{l}0.000586 \\
(0.00410)\end{array}$ & $\begin{array}{c}0.00209 \\
(0.00642)\end{array}$ & $\begin{array}{c}0.00171 \\
(0.00417)\end{array}$ \\
\hline$($ His Age -60$) *\left(1-D_{m}\right)$ & $\begin{array}{c}-0.00732 \\
(0.261)\end{array}$ & & $\begin{array}{c}-0.0376 \\
(0.264)\end{array}$ & $\begin{array}{l}0.437 * \\
(0.226)\end{array}$ & $\begin{array}{l}-0.222 \\
(0.273)\end{array}$ & $\begin{array}{c}0.452 * * \\
(0.231)\end{array}$ \\
\hline$(\text { His Age }-60)^{2} *\left(1-D_{m}\right)$ & $\begin{array}{c}-0.136^{* *} \\
(0.0688)\end{array}$ & & $\begin{array}{c}-0.144 * * \\
(0.0693)\end{array}$ & $\begin{array}{l}0.0911 * \\
(0.0533)\end{array}$ & $\begin{array}{c}-0.190 * * * \\
(0.0721)\end{array}$ & $\begin{array}{l}0.0969 * \\
(0.0542)\end{array}$ \\
\hline$(\text { His Age }-60)^{3 *}\left(1-D_{m}\right)$ & $\begin{array}{c}-0.0121 * * \\
(0.00486)\end{array}$ & & $\begin{array}{c}-0.0127 * * * \\
(0.00488)\end{array}$ & $\begin{array}{c}0.00511 \\
(0.00355)\end{array}$ & $\begin{array}{c}-0.0156 * * * \\
(0.00507)\end{array}$ & $\begin{array}{c}0.00557 \\
(0.00361)\end{array}$ \\
\hline She is age $>=60\left(D_{f}\right)$ & & $\begin{array}{c}0.899 * * \\
(0.365)\end{array}$ & $\begin{array}{l}-0.462 \\
(0.430)\end{array}$ & $\begin{array}{c}0.941 * * \\
(0.370)\end{array}$ & $\begin{array}{l}-0.445 \\
(0.439)\end{array}$ & $\begin{array}{c}1.017 * * * \\
(0.372)\end{array}$ \\
\hline$($ She Age -60$) * D_{f}$ & & $\begin{array}{l}0.0264 \\
(0.312)\end{array}$ & $\begin{array}{l}0.599 * \\
(0.307)\end{array}$ & $\begin{array}{c}-0.00378 \\
(0.318)\end{array}$ & $\begin{array}{c}0.633 * * \\
(0.308)\end{array}$ & $\begin{array}{l}0.0301 \\
(0.322)\end{array}$ \\
\hline$(\text { She Age }-60)^{2} * D_{f}$ & & $\begin{array}{r}-0.00507 \\
(0.0966)\end{array}$ & $\begin{array}{l}-0.0857 \\
(0.0834)\end{array}$ & $\begin{array}{c}-0.00645 \\
(0.0989)\end{array}$ & $\begin{array}{c}-0.0998 \\
(0.0827)\end{array}$ & $\begin{array}{r}-0.0183 \\
(0.101)\end{array}$ \\
\hline$(\text { She Age }-60)^{3}{ }^{*} D_{f}$ & & $\begin{array}{c}0.00247 \\
(0.00836)\end{array}$ & $\begin{array}{c}0.00274 \\
(0.00612)\end{array}$ & $\begin{array}{c}0.00284 \\
(0.00858)\end{array}$ & $\begin{array}{c}0.00387 \\
(0.00599)\end{array}$ & $\begin{array}{c}0.00376 \\
(0.00877)\end{array}$ \\
\hline$($ She Age -60$) *\left(1-D_{f}\right)$ & & $\begin{array}{l}0.0256 \\
(0.177)\end{array}$ & $\begin{array}{c}-0.0277 \\
(0.260)\end{array}$ & $\begin{array}{c}-0.0870 \\
(0.182)\end{array}$ & $\begin{array}{c}-0.0783 \\
(0.271)\end{array}$ & $\begin{array}{l}-0.169 \\
(0.184)\end{array}$ \\
\hline$(\text { She Age }-60)^{2} *\left(1-D_{f}\right)$ & & $\begin{array}{l}-0.0196 \\
(0.0390)\end{array}$ & $\begin{array}{c}-0.00383 \\
(0.0570)\end{array}$ & $\begin{array}{l}-0.0285 \\
(0.0399)\end{array}$ & $\begin{array}{l}-0.0177 \\
(0.0591)\end{array}$ & $\begin{array}{l}-0.0456 \\
(0.0404)\end{array}$ \\
\hline$(\text { She Age }-60)^{3} *\left(1-D_{f}\right)$ & & $\begin{array}{l}-0.00138 \\
(0.00247)\end{array}$ & $\begin{array}{r}-0.000172 \\
(0.00363)\end{array}$ & $\begin{array}{l}-0.00150 \\
(0.00252)\end{array}$ & $\begin{array}{l}-0.00115 \\
(0.00376)\end{array}$ & $\begin{array}{l}-0.00252 \\
(0.00256)\end{array}$ \\
\hline He high school & & & & & $\begin{array}{l}-0.265 \\
(0.199)\end{array}$ & $\begin{array}{c}0.192 \\
(0.152)\end{array}$ \\
\hline He College & & & & & $\begin{array}{c}-0.604 * * * \\
(0.216)\end{array}$ & $\begin{array}{c}0.235 \\
(0.163)\end{array}$ \\
\hline He high school & & & & & $\begin{array}{l}0.381 * \\
(0.221)\end{array}$ & $\begin{array}{l}-0.134 \\
(0.167)\end{array}$ \\
\hline He College & & & & & $\begin{array}{l}-0.0995 \\
(0.246)\end{array}$ & $\begin{array}{c}-0.701 * * * \\
(0.181)\end{array}$ \\
\hline Constant & $\begin{array}{c}0.289 \\
(0.258)\end{array}$ & $\begin{array}{l}0.423 * \\
(0.231) \\
\end{array}$ & $\begin{array}{c}0.174 \\
(0.436)\end{array}$ & $\begin{array}{c}0.408 \\
(0.353)\end{array}$ & $\begin{array}{l}0.0901 \\
(0.452) \\
\end{array}$ & $\begin{array}{c}0.344 \\
(0.357) \\
\end{array}$ \\
\hline $\begin{array}{l}\text { Observations: } \\
\text { Standard errors in paren } \\
\text { Notice these are estimat } \\
{ }^{* \star *} p<0.01,{ }^{* \star} p<0.05,{ }^{*} p\end{array}$ & $\begin{array}{l}1043 \\
\text { ses. } \\
\text { coefficients. N } \\
1 \\
\end{array}$ & estimates & and Df ar & led in Table 4 & & \\
\hline
\end{tabular}




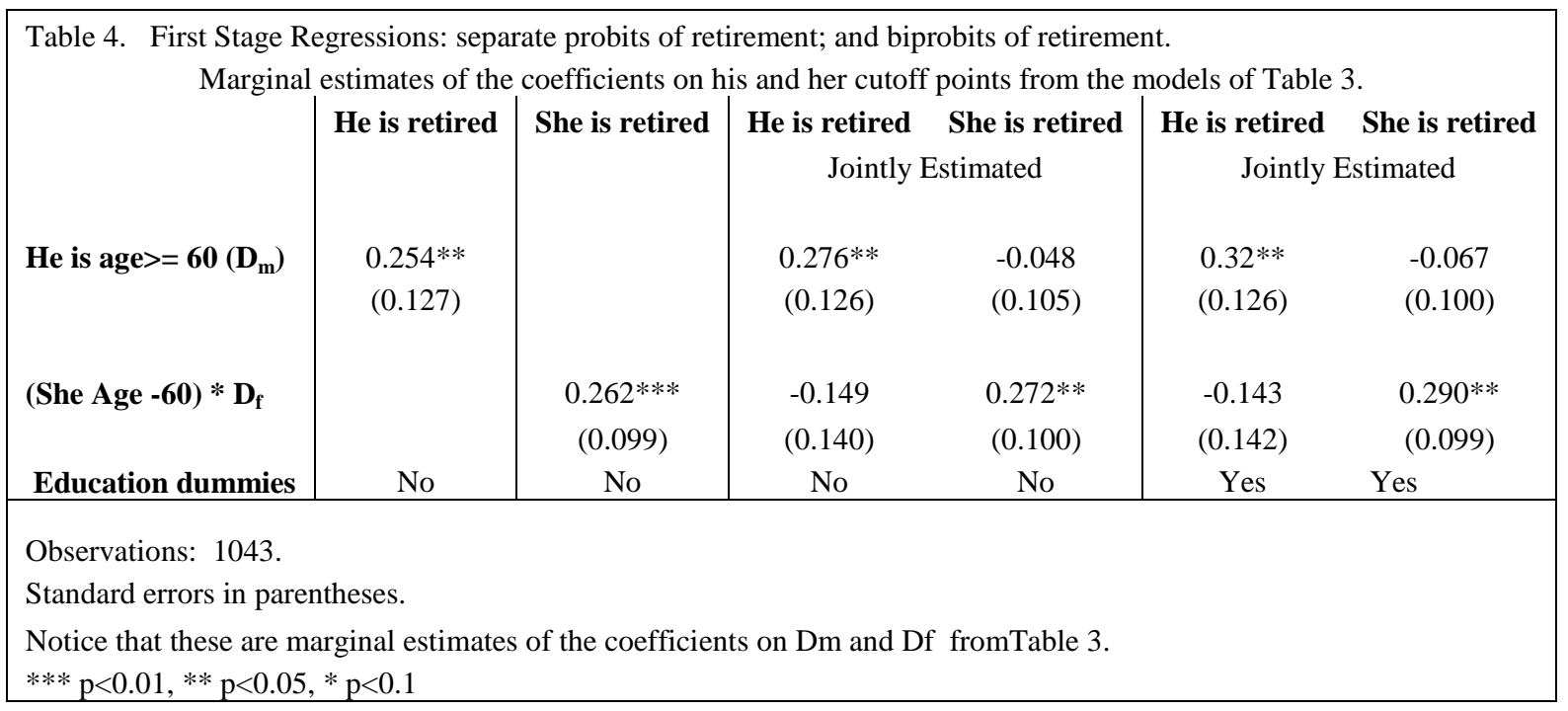




\begin{tabular}{|c|c|c|c|c|c|}
\hline & He retired & $\begin{array}{l}\text { She } \\
\text { retired }\end{array}$ & $\begin{array}{c}\text { His disj. } \\
\text { leisure }\end{array}$ & $\begin{array}{c}\text { Her disj. } \\
\text { leisure }\end{array}$ & Joint Leisure \\
\hline He high Educ. & $\begin{array}{l}-0.222 \\
(0.189)\end{array}$ & $\begin{array}{c}0.132 \\
(0.151)\end{array}$ & $\begin{array}{c}22.76 \\
(17.59)\end{array}$ & $\begin{array}{l}-10.68 \\
(14.41)\end{array}$ & $\begin{array}{l}-3.402 \\
(12.09)\end{array}$ \\
\hline He College Educ. & $\begin{array}{c}-0.535 * * * \\
(0.202)\end{array}$ & $\begin{array}{c}0.190 \\
(0.168)\end{array}$ & $\begin{array}{c}42.07 * * \\
(20.22)\end{array}$ & $\begin{array}{c}35.25 * * \\
(16.27)\end{array}$ & $\begin{array}{l}-8.324 \\
(13.24)\end{array}$ \\
\hline She high Educ. & $\begin{array}{c}0.340 \\
(0.212)\end{array}$ & $\begin{array}{l}-0.0627 \\
(0.169)\end{array}$ & $\begin{array}{c}1.861 \\
(19.57)\end{array}$ & $\begin{array}{c}13.14 \\
(16.03)\end{array}$ & $\begin{array}{l}-1.076 \\
(13.40)\end{array}$ \\
\hline $\begin{array}{l}\text { She College } \\
\text { Educ. }\end{array}$ & $\begin{array}{c}-0.0234 \\
(0.235)\end{array}$ & $\begin{array}{c}-0.619 * * * \\
(0.184)\end{array}$ & $\begin{array}{c}1.102 \\
(33.73)\end{array}$ & $\begin{array}{l}37.87 * \\
(22.80)\end{array}$ & $\begin{array}{l}-19.20 \\
(17.10)\end{array}$ \\
\hline Dm & $\begin{array}{c}0.710 * * \\
(0.361)\end{array}$ & $\begin{array}{l}-0.125 \\
(0.309)\end{array}$ & & & \\
\hline Df & $\begin{array}{l}-0.127 \\
(0.420)\end{array}$ & $\begin{array}{c}1.023 * * * \\
(0.337)\end{array}$ & & & \\
\hline Winter Diary & & & $\begin{array}{c}3.694 \\
(11.72)\end{array}$ & $\begin{array}{c}13.97 \\
(9.862)\end{array}$ & $\begin{array}{c}8.289 \\
(7.730)\end{array}$ \\
\hline Weekend diary & & & $\begin{array}{c}80.19 * * * \\
(12.42)\end{array}$ & $\begin{array}{c}55.68 * * * \\
(10.21)\end{array}$ & $\begin{array}{c}27.71 * * * \\
(8.082)\end{array}$ \\
\hline His Age -60 & & & $\begin{array}{c}-14.23 * * \\
(6.264)\end{array}$ & $\begin{array}{l}-5.735 \\
(4.516)\end{array}$ & $\begin{array}{c}6.123 \\
(4.141)\end{array}$ \\
\hline$(\text { His Age }-60)^{2}$ & & & $\begin{array}{c}0.724 * * * \\
(0.259)\end{array}$ & $\begin{array}{l}0.0993 \\
(0.208)\end{array}$ & $\begin{array}{l}-0.226 \\
(0.164)\end{array}$ \\
\hline$(\text { His Age }-60)^{3}$ & & & $\begin{array}{l}0.133 * * \\
(0.0586)\end{array}$ & $\begin{array}{c}0.0292 \\
(0.0422)\end{array}$ & $\begin{array}{l}-0.0280 \\
(0.0372)\end{array}$ \\
\hline Her Age -60 & & & $\begin{array}{l}-1.516 \\
(5.859)\end{array}$ & $\begin{array}{c}4.278 \\
(3.683)\end{array}$ & $\begin{array}{l}-2.509 \\
(2.569)\end{array}$ \\
\hline$(\text { Her Age -60 })^{2}$ & & & $\begin{array}{l}-0.422 * \\
(0.252)\end{array}$ & $\begin{array}{l}-0.165 \\
(0.195)\end{array}$ & $\begin{array}{l}0.0324 \\
(0.160)\end{array}$ \\
\hline$(\text { Her Age }-60)^{3}$ & & & $\begin{array}{l}-0.0248 \\
(0.0416)\end{array}$ & $\begin{array}{c}-0.0913 * * * \\
(0.0323)\end{array}$ & $\begin{array}{c}0.0272 \\
(0.0266)\end{array}$ \\
\hline He Retired & & & $\begin{array}{c}249.8 * * * \\
(44.23)\end{array}$ & $\begin{array}{c}49.79 \\
(35.70)\end{array}$ & $\begin{array}{c}-52.48 * \\
(28.60)\end{array}$ \\
\hline She retired & & & $\begin{array}{r}-7.063 \\
(137.5) \\
\end{array}$ & $\begin{array}{c}92.93 \\
(77.70) \\
\end{array}$ & $\begin{array}{c}138.2 * * * \\
(43.13)\end{array}$ \\
\hline \multicolumn{6}{|c|}{$\begin{array}{l}\text { This is the strictest definition of joint leisure that we use, requiring both partners to carry out exactly } \\
\text { the same leisure activity on the same moment and both partners to report to have done this with } \\
\text { family (see Section } 3.2 \text { ). } \\
\text { Coefficients on the age polynomials interacted with the cuts off from the right and the left not shown } \\
\text { (See table } 3 \text { for the raw estimates). Constants are not shown either. } \\
* * * p<0.01, * * p<0.05, * p<0.1 \\
\text { Standard errors in parentheses. }\end{array}$} \\
\hline
\end{tabular}




\begin{tabular}{|c|c|c|c|c|}
\hline & She retired & His leisure & Her leisure & Joint leisure \\
\hline He retired & $\begin{array}{l}0.281^{* * *} \\
(0.0984)\end{array}$ & $\begin{array}{c}-0.431^{\star *} \\
(0.175)\end{array}$ & $\begin{array}{c}-0.303^{* *} \\
(0.144)\end{array}$ & $\begin{array}{c}0.543^{* * *} \\
(0.202)\end{array}$ \\
\hline She retired & & $\begin{array}{c}-0.0678 \\
(0.503)\end{array}$ & $\begin{array}{l}-0.134 \\
(0.339)\end{array}$ & $\begin{array}{l}-0.490^{*} \\
(0.272)\end{array}$ \\
\hline His leisure & & & $\begin{array}{l}0.479^{\star * *} \\
(0.0424)\end{array}$ & $\begin{array}{c}-0.443^{\star \star \star} \\
(0.104)\end{array}$ \\
\hline Her leisure & & & & $\begin{array}{c}-0.467^{\star \star *} \\
(0.0710) \\
\end{array}$ \\
\hline
\end{tabular}


Table 7. Results of estimation of joint leisure, assuming that retirement choices are exogenous

Leisure Time Together (definition a)

He high Educ.

2.807

(11.04)

He College Educ.

7.343

(11.98)

She high Educ.

$-9.631$

(12.23)

She College Educ.

$-35.00 * * *$

(13.51)

9.310

Winter Diary

(7.805)

Weekend diary

$24.11 * * *$

(7.968)

His Age -60

$-2.557$

(2.198)

(His Age -60) ${ }^{2}$

0.121

(0.142)

(His Age -60) ${ }^{3}$

0.0163

(0.0237)

Her Age -60

0.566

(1.778)

$-0.0599$

(Her Age -60) ${ }^{2}$

$(0.142)$

(Her Age -60) ${ }^{3}$

0.0163

(0.0237)

He Retired

$62.23 * * *$

(12.36)

She retired

$39.46 * * *$

(8.597)

Standard errors in parentheses. $* * * \mathrm{p}<0.01, * * \mathrm{p}<0.05, * \mathrm{p}<0.1$.

Constant not shown. 


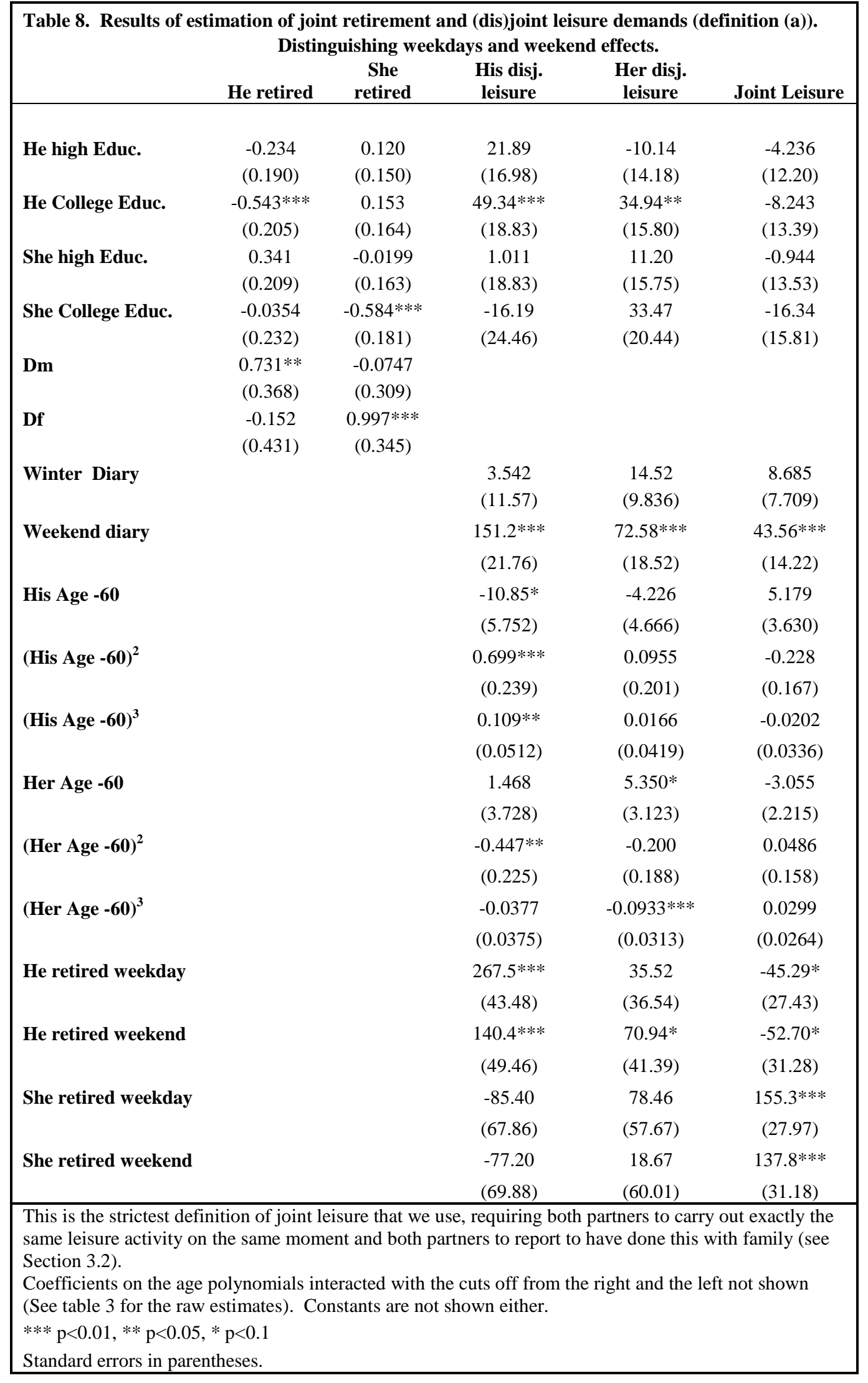




\begin{tabular}{|c|c|c|c|c|c|}
\hline Distinguishing $\mathbf{w}$ & kdays and $\mathrm{w}$ & kend effect & nd controll & both partn & retired. \\
\hline & He retired & $\begin{array}{l}\text { She } \\
\text { retired }\end{array}$ & $\begin{array}{c}\text { His disj. } \\
\text { leisure }\end{array}$ & $\begin{array}{c}\text { Her disj. } \\
\text { leisure }\end{array}$ & Joint Leisure \\
\hline He high Educ. & -0.236 & 0.187 & 22.43 & -6.803 & -3.518 \\
\hline & $(0.189)$ & $(0.146)$ & $(17.25)$ & (15.37) & (12.47) \\
\hline He College Educ. & $-0.525 * * *$ & 0.215 & $50.77 * * *$ & $39.96 * *$ & -7.169 \\
\hline & $(0.203)$ & $(0.157)$ & $(19.02)$ & (16.97) & (13.68) \\
\hline She high Educ. & 0.286 & -0.0434 & 0.501 & 6.528 & -1.069 \\
\hline & $(0.207)$ & $(0.161)$ & (19.20) & $(17.11)$ & (13.85) \\
\hline She College Educ. & -0.0467 & $-0.586 * * *$ & -21.93 & 6.072 & -15.19 \\
\hline & $(0.230)$ & $(0.174)$ & (22.77) & (19.89) & $(15.76)$ \\
\hline Dm & $0.684^{*}$ & 0.0397 & & & \\
\hline & $(0.380)$ & $(0.298)$ & & & \\
\hline Df & -0.348 & $0.889 * *$ & & & \\
\hline & $(0.547)$ & $(0.443)$ & & & \\
\hline Dm * Df & 0.109 & -0.454 & & & \\
\hline & $(0.369)$ & $(0.333)$ & & & \\
\hline Winter Diary & & & 1.989 & 12.30 & 10.50 \\
\hline & & & (11.56) & $(9.776)$ & (7.683) \\
\hline Weekend diary & & & $162.6 * * *$ & $82.48 * * *$ & $32.79 * *$ \\
\hline & & & $(23.96)$ & (19.93) & $(15.71)$ \\
\hline His Age -60 & & & $-10.72 * *$ & 0.983 & 4.684 \\
\hline & & & $(5.420)$ & (4.388) & $(3.575)$ \\
\hline$(\text { His Age }-60)^{2}$ & & & $0.747 * * *$ & 0.185 & -0.248 \\
\hline & & & $(0.240)$ & $(0.213)$ & $(0.169)$ \\
\hline$(\text { His Age }-60)^{3}$ & & & $0.105^{* *}$ & -0.0304 & -0.0162 \\
\hline & & & $(0.0490)$ & $(0.0410)$ & $(0.0335)$ \\
\hline Her Age -60 & & & 3.103 & $11.78 * * *$ & $-4.146^{*}$ \\
\hline & & & (3.353) & $(2.826)$ & (2.209) \\
\hline$(\text { Her Age }-60)^{2}$ & & & $-0.481 * *$ & $-0.343^{*}$ & 0.0664 \\
\hline & & & $(0.225)$ & $(0.200)$ & $(0.161)$ \\
\hline$(\text { Her Age }-60)^{3}$ & & & -0.0442 & $-0.119 * * *$ & 0.0343 \\
\hline & & & $(0.0376)$ & $(0.0332)$ & $(0.0269)$ \\
\hline He retired* weekday & & & $295.2 * * *$ & $61.45^{*}$ & $-70.82 * * *$ \\
\hline & & & $(42.94)$ & $(36.13)$ & $(26.53)$ \\
\hline He retired $*$ weekend & & & $136.0^{* *}$ & 69.27 & -54.88 \\
\hline & & & $(56.02)$ & $(47.48)$ & $(35.20)$ \\
\hline She retired *weekday & & & $-108.9 * *$ & -47.44 & $150.6^{* * *}$ \\
\hline & & & $(45.15)$ & $(37.57)$ & $(22.57)$ \\
\hline She retired $*$ weekend & & & $-133.8 * *$ & $-137.1 * * *$ & $162.2 * * *$ \\
\hline & & & $(56.11)$ & $(45.42)$ & $(30.65)$ \\
\hline Both retired* weekday & & & -31.25 & $-56.18 * *$ & $45.18^{* *}$ \\
\hline & & & $(28.60)$ & $(22.82)$ & (18.54) \\
\hline Both retired * weekend & & & 27.98 & -6.933 & -1.264 \\
\hline & & & $(49.37)$ & $(41.01)$ & $(31.33)$ \\
\hline $\begin{array}{l}\text { Coefficients on the age } \mathrm{p} \\
\text { table } 3 \text { for the raw estima } \\
* * * \mathrm{p}<0.01, * * \mathrm{p}<0.05, *\end{array}$ & $\begin{array}{l}\text { omials in } \\
\text { Consta } \\
\end{array}$ & $\begin{array}{l}\text { with } \\
\text { ot she }\end{array}$ & $\begin{array}{l}\text { off from th } \\
\text { r. Standar }\end{array}$ & $\begin{array}{l}\text { and the le } \\
\text { in parent }\end{array}$ & shown (See \\
\hline
\end{tabular}




\begin{tabular}{|c|c|c|c|c|c|}
\hline & He retired & She retired & His disj. leisure & Her disj. leisure & Joint Leisure \\
\hline He high Educ. & $\begin{array}{c}-0.0898 \\
(0.210)\end{array}$ & $\begin{array}{c}0.188 \\
(0.171)\end{array}$ & $\begin{array}{l}32.74 * \\
(19.73)\end{array}$ & $\begin{array}{l}-8.245 \\
(16.50)\end{array}$ & $\begin{array}{l}-11.09 \\
(14.02)\end{array}$ \\
\hline He College Educ. & $\begin{array}{l}-0.424 * \\
(0.229)\end{array}$ & $\begin{array}{c}0.138 \\
(0.186)\end{array}$ & $\begin{array}{c}47.91 * * \\
(22.48)\end{array}$ & $\begin{array}{c}26.16 \\
(18.76)\end{array}$ & $\begin{array}{l}-9.792 \\
(15.91)\end{array}$ \\
\hline She high Educ. & $\begin{array}{c}0.251 \\
(0.235)\end{array}$ & $\begin{array}{c}0.00692 \\
(0.180)\end{array}$ & $\begin{array}{l}-21.55 \\
(22.07)\end{array}$ & $\begin{array}{c}12.08 \\
(18.53)\end{array}$ & $\begin{array}{c}4.100 \\
(15.79)\end{array}$ \\
\hline She College Educ. & $\begin{array}{c}-0.287 \\
(0.268)\end{array}$ & $\begin{array}{c}-0.535^{* *} \\
(0.208)\end{array}$ & $\begin{array}{c}12.17 \\
(26.44)\end{array}$ & $\begin{array}{c}53.68 * * \\
(21.83)\end{array}$ & $\begin{array}{c}-24.24 \\
(18.35)\end{array}$ \\
\hline Dm & $\begin{array}{c}0.918 * * * \\
(0.336)\end{array}$ & $\begin{array}{c}-0.141 \\
(0.251)\end{array}$ & & & \\
\hline Df & $\begin{array}{c}-0.207 \\
(0.373)\end{array}$ & $\begin{array}{c}0.963 * * * \\
(0.300)\end{array}$ & & & \\
\hline Winter Diary & & & $\begin{array}{l}-7.705 \\
(13.86)\end{array}$ & $\begin{array}{c}4.897 \\
(11.62)\end{array}$ & $\begin{array}{c}20.43^{* *} \\
(9.194)\end{array}$ \\
\hline Weekend diary & & & $\begin{array}{c}73.91 * * * \\
(14.50)\end{array}$ & $\begin{array}{c}55.68 * * * \\
(12.16)\end{array}$ & $\begin{array}{c}30.15^{* * *} * \\
(9.636)\end{array}$ \\
\hline His Age -60 & & & $\begin{array}{c}-7.409 * \\
(4.125)\end{array}$ & $\begin{array}{l}-2.145 \\
(3.313)\end{array}$ & $\begin{array}{l}5.182 * \\
(2.653)\end{array}$ \\
\hline$(\text { His Age }-60)^{2}$ & & & $\begin{array}{c}0.882 * * \\
(0.447)\end{array}$ & $\begin{array}{l}-0.114 \\
(0.365)\end{array}$ & $\begin{array}{l}-0.187 \\
(0.302)\end{array}$ \\
\hline Her Age -60 & & & $\begin{array}{l}-3.191 \\
(2.588)\end{array}$ & $\begin{array}{l}-0.190 \\
(2.018)\end{array}$ & $\begin{array}{l}-2.282 \\
(1.615)\end{array}$ \\
\hline$(\text { Her Age }-60)^{2}$ & & & $\begin{array}{l}-0.384 \\
(0.361)\end{array}$ & $\begin{array}{c}0.262 \\
(0.302)\end{array}$ & $\begin{array}{l}-0.325 \\
(0.257)\end{array}$ \\
\hline He Retired & & & $\begin{array}{c}213.3 * * * \\
(47.71)\end{array}$ & $\begin{array}{c}22.72 \\
(36.61)\end{array}$ & $\begin{array}{c}-56.34 * * \\
(27.93)\end{array}$ \\
\hline She retired & & & $\begin{array}{c}28.88 \\
(55.32)\end{array}$ & $\begin{array}{c}129.1 * * * \\
(37.63)\end{array}$ & $\begin{array}{c}142.8 * * * \\
(25.18)\end{array}$ \\
\hline \multicolumn{6}{|c|}{$\begin{array}{l}\text { We keep partners aged } 52 \text { to } 68 \text { included. The sample size is } 746 \text { observations. Coefficients on } \\
\text { the age polynomials interacted with the cuts off from the right and the left not shown (See table } 3 \text { for } \\
\text { the raw estimates). Constants are not shown either. Here we enter quadratic polynomials in age, } \\
\text { interacted with the cutoffs in the retirement probability equations. } \\
* * * p<0.01, * * p<0.05, * \mathrm{p}<0.1 \\
\text { Standard errors in parentheses. }\end{array}$} \\
\hline
\end{tabular}




\begin{tabular}{|c|c|c|c|c|c|}
\hline & He retired & $\begin{array}{c}\text { She } \\
\text { retired }\end{array}$ & $\begin{array}{c}\text { His disj. } \\
\text { leisure }\end{array}$ & $\begin{array}{c}\text { Her disj. } \\
\text { leisure }\end{array}$ & Joint Leisure \\
\hline He high Educ. & $\begin{array}{l}-0.188 \\
(0.207)\end{array}$ & $\begin{array}{c}0.145 \\
(0.185)\end{array}$ & $\begin{array}{c}35.08 \\
(21.76)\end{array}$ & $\begin{array}{l}-9.919 \\
(17.71)\end{array}$ & $\begin{array}{l}-6.805 \\
(15.18)\end{array}$ \\
\hline He College Educ. & $\begin{array}{l}-0.409 * \\
(0.236)\end{array}$ & $\begin{array}{l}0.0659 \\
(0.204)\end{array}$ & $\begin{array}{l}62.31 * * \\
(25.74)\end{array}$ & $\begin{array}{c}23.58 \\
(20.91)\end{array}$ & $\begin{array}{l}-2.594 \\
(17.88)\end{array}$ \\
\hline She high Educ. & $\begin{array}{c}0.258 \\
(0.241)\end{array}$ & $\begin{array}{l}0.0365 \\
(0.193)\end{array}$ & $\begin{array}{l}-40.76 \\
(24.87)\end{array}$ & $\begin{array}{c}13.61 \\
(20.24)\end{array}$ & $\begin{array}{c}8.943 \\
(17.39)\end{array}$ \\
\hline Educ. & $\begin{array}{l}-0.343 \\
(0.269)\end{array}$ & $\begin{array}{c}-0.555 * * \\
(0.224)\end{array}$ & $\begin{array}{c}11.90 \\
(29.22)\end{array}$ & $\begin{array}{c}70.15^{* * * *} \\
(23.92)\end{array}$ & $\begin{array}{l}-29.28 \\
(20.28)\end{array}$ \\
\hline Dm & $\begin{array}{c}0.967 * * * \\
(0.352)\end{array}$ & $\begin{array}{r}-0.0402 \\
(0.281)\end{array}$ & & & \\
\hline Df & $\begin{array}{c}-0.0134 \\
(0.373)\end{array}$ & $\begin{array}{c}0.805 * * \\
(0.323)\end{array}$ & & & \\
\hline Winter Diary & & & $\begin{array}{l}-5.117 \\
(15.27)\end{array}$ & $\begin{array}{l}0.0756 \\
(12.57)\end{array}$ & $\begin{array}{c}17.20 * \\
(10.01)\end{array}$ \\
\hline Weekend diary & & & $\begin{array}{c}82.38 * * * \\
(16.22)\end{array}$ & $\begin{array}{c}45.20 * * * \\
(13.36)\end{array}$ & $\begin{array}{c}25.26 * * \\
(10.62)\end{array}$ \\
\hline His Age -60 & & & $\begin{array}{c}-11.87 * * \\
(4.757)\end{array}$ & $\begin{array}{c}-8.706^{* *} \\
(3.762)\end{array}$ & $\begin{array}{c}9.446 * * * \\
(3.063)\end{array}$ \\
\hline$(\text { His Age }-60)^{2}$ & & & $\begin{array}{l}1.085^{*} \\
(0.651)\end{array}$ & $\begin{array}{c}0.727 \\
(0.523)\end{array}$ & $\begin{array}{l}-0.212 \\
(0.438)\end{array}$ \\
\hline Her Age -60 & & & $\begin{array}{c}-6.378 * * \\
(2.912)\end{array}$ & $\begin{array}{c}0.872 \\
(2.415)\end{array}$ & $\begin{array}{l}-1.799 \\
(1.964)\end{array}$ \\
\hline$(\text { Her Age -60 })^{2}$ & & & $\begin{array}{l}-0.402 \\
(0.540)\end{array}$ & $\begin{array}{c}0.464 \\
(0.440)\end{array}$ & $\begin{array}{c}0.142 \\
(0.378)\end{array}$ \\
\hline He Retired & & & $\begin{array}{c}236.7 * * * \\
(45.56)\end{array}$ & $\begin{array}{l}58.66 * \\
(34.88)\end{array}$ & $\begin{array}{c}-81.61 * * * \\
(25.72)\end{array}$ \\
\hline She retired & & & $\begin{array}{r}65.95 \\
(48.89) \\
\end{array}$ & $\begin{array}{c}136.4 * * * \\
(41.93) \\
\end{array}$ & $\begin{array}{c}140.8 * * * \\
(28.53)\end{array}$ \\
\hline \multicolumn{6}{|c|}{$\begin{array}{l}\text { We keep partners aged } 53 \text { to } 67 \text { included. The sample size is } 618 \text { observations. Coefficients on the } \\
\text { age polynomials interacted with the cuts off from the right and the left not shown (See table } 3 \text { for the } \\
\text { raw estimates). Constants are not shown either. Here we enter quadratic polynomials in age, } \\
\text { interacted with the cutoffs in the retirement probability equations. } \\
* * * p<0.01, * * p<0.05, * p<0.1 \\
\text { Standard errors in parentheses. }\end{array}$} \\
\hline
\end{tabular}




\begin{tabular}{|c|c|c|c|c|c|}
\hline & $\begin{array}{c}\mathrm{He} \\
\text { retired }\end{array}$ & She retired & $\begin{array}{c}\text { His disj. } \\
\text { leisure }\end{array}$ & $\begin{array}{c}\text { Her disj. } \\
\text { leisure }\end{array}$ & Joint Leisure \\
\hline He high Educ. & $\begin{array}{l}-0.331 \\
(0.226)\end{array}$ & $\begin{array}{c}-0.00433 \\
(0.197)\end{array}$ & $\begin{array}{c}35.70 \\
(25.50)\end{array}$ & $\begin{array}{l}-16.86 \\
(19.55)\end{array}$ & $\begin{array}{c}-6.082 \\
(16.92)\end{array}$ \\
\hline He College Educ. & $\begin{array}{l}-0.420 \\
(0.262)\end{array}$ & $\begin{array}{l}-0.0457 \\
(0.232)\end{array}$ & $\begin{array}{c}76.07 * * \\
(30.44)\end{array}$ & $\begin{array}{c}19.54 \\
(23.30)\end{array}$ & $\begin{array}{c}2.809 \\
(20.15)\end{array}$ \\
\hline She high Educ. & $\begin{array}{c}0.187 \\
(0.261)\end{array}$ & $\begin{array}{l}0.0312 \\
(0.212)\end{array}$ & $\begin{array}{l}-44.42 \\
(28.61)\end{array}$ & $\begin{array}{c}24.20 \\
(21.95)\end{array}$ & $\begin{array}{c}11.04 \\
(19.01)\end{array}$ \\
\hline She College Educ. & $\begin{array}{l}-0.400 \\
(0.292)\end{array}$ & $\begin{array}{c}-0.351 \\
(0.246)\end{array}$ & $\begin{array}{c}8.744 \\
(32.52)\end{array}$ & $\begin{array}{c}79.07 * * * \\
(25.02)\end{array}$ & $\begin{array}{c}-41.48 * \\
(21.62)\end{array}$ \\
\hline Dm & $\begin{array}{c}0.987 * * \\
(0.397)\end{array}$ & $\begin{array}{l}-0.0481 \\
(0.308)\end{array}$ & & & \\
\hline Df & $\begin{array}{l}-0.146 \\
(0.398)\end{array}$ & $\begin{array}{c}0.779 * * \\
(0.328)\end{array}$ & & & \\
\hline Winter Diary & & & $\begin{array}{l}-13.22 \\
(17.29)\end{array}$ & $\begin{array}{l}-12.42 \\
(13.80)\end{array}$ & $\begin{array}{c}19.95^{*} \\
(11.13)\end{array}$ \\
\hline Weekend diary & & & $\begin{array}{c}64.67 * * * \\
(17.94)\end{array}$ & $\begin{array}{c}38.37 * * * \\
(14.40)\end{array}$ & $\begin{array}{c}28.62 * * \\
(11.59)\end{array}$ \\
\hline His Age -60 & & & $\begin{array}{c}-18.40 * * * \\
(5.650)\end{array}$ & $\begin{array}{c}-11.73 * * * \\
(4.190)\end{array}$ & $\begin{array}{c}10.65 * * * \\
(3.597)\end{array}$ \\
\hline$(\text { His Age }-60)^{2}$ & & & $\begin{array}{l}1.774 * \\
(0.914)\end{array}$ & $\begin{array}{c}1.125 \\
(0.693)\end{array}$ & $\begin{array}{l}-0.218 \\
(0.598)\end{array}$ \\
\hline Her Age -60 & & & $\begin{array}{c}-7.440 * * \\
(3.709)\end{array}$ & $\begin{array}{c}1.130 \\
(2.891)\end{array}$ & $\begin{array}{l}-2.611 \\
(2.417)\end{array}$ \\
\hline$(\text { Her Age -60 })^{2}$ & & & $\begin{array}{l}-0.821 \\
(0.806)\end{array}$ & $\begin{array}{c}0.363 \\
(0.619)\end{array}$ & $\begin{array}{c}0.349 \\
(0.536)\end{array}$ \\
\hline He Retired & & & $\begin{array}{c}294.4 * * * \\
(50.46)\end{array}$ & $\begin{array}{c}71.88 * * \\
(35.66)\end{array}$ & $\begin{array}{c}-77.21 * * * \\
(28.99)\end{array}$ \\
\hline She retired & & & $\begin{array}{l}85.68 * \\
(51.75) \\
\end{array}$ & $\begin{array}{c}139.6^{* * * *} \\
(41.52) \\
\end{array}$ & $\begin{array}{c}138.7 * * * \\
(30.52) \\
\end{array}$ \\
\hline \multicolumn{6}{|c|}{$\begin{array}{l}\text { We keep partners aged } 54 \text { to } 66 \text { included. The sample size is } 506 \text { observations. Coefficients on the age } \\
\text { polynomials interacted with the cuts off from the right and the left not shown (See table } 3 \text { for the raw } \\
\text { estimates). Constants are not shown either. Here we enter quadratic polynomials in age, interacted } \\
\text { with the cutoffs in the retirement probability equations. } \\
* * * p<0.01, * * p<0.05, * p<0.1 \\
\text { Standard errors in parentheses. }\end{array}$} \\
\hline
\end{tabular}

